\title{
PERCEPTIONS OF SPECIAL EDUCATION TRAINING AS VIEWED \\ BY NORTHWEST MISSOURI HIGH SCHOOL PRINCIPALS AND MISSOURI \\ UNIVERSITY LEADERS
}

\author{
A Dissertation \\ Presented to \\ the Faculty of the Graduate School \\ at the University of Missouri-Columbia \\ In Partial Fulfillment \\ of the Requirements for the Degree \\ Doctor of Education \\ By \\ LUCAS (LUKE) W. MCCOY \\ Dr. Carole Edmonds, Dissertation Supervisor
}

JULY 2018 
The undersigned, appointed by the dean of the Graduate School, have examined the dissertation entitled

PERCEPTIONS OF SPECIAL EDUCATION TRAINING AS VIEWED

BY NORTHWEST MISSOURI HIGH SCHOOL PRINCIPALS AND MISSOURI UNIVERSITY LEADERS

\begin{abstract}
Presented by Lucas (Luke) W. McCoy, a candidate for the degree of Doctor of Education and herby certify that, in their opinion, is worthy of acceptance.
\end{abstract}

Dr. Carole Edmonds, Dissertation Supervisor

Dr. Tim Wall

Dr. Bill Hedge

Dr. Jennee Gregory 


\section{ACKNOWLEDGEMENTS}

* Dr. Carole Edmonds has been very supportive throughout the coursework and dissertation work. She has been wonderful to work with and I've certainly appreciated the guidance she has given me. Dr. Edmonds provided me with more than university coursework, listening to my professional concerns and giving sage advice when needed.

* Thank you to Dr. Tim Wall, Dr. Bill Hedge and Dr. Jennee Gregory for the willingness to serve on the dissertation team. I appreciate their honest feedback and direction throughout the process. It is especially an honor to have Dr. Hedge on the committee, who served as a mentor to me during my first few years of teaching at Central High School.

* Much appreciation to the participants who carved out time to share their perceptions with me. Several I've know for some time and it is always good to hear their perspectives on important educational issues.

* Thanks to all of my coworkers at Benton and the district who have supported and encouraged along the way. Thank you Cohort 8!

* Thank you to all of my grandparents, aunts and uncles, cousins, my wife's parents and other extended family and friends for their support: Growing up here in St. Joseph they provided love and support throughout. Special thanks to my uncle Bill, who paved the way for the beginning of my teaching career.

* To my sister, Deanna, and my brother-in-law, Trond, thank you for the love and support.

* My mom and dad, Judy and Larry McCoy who have supported and encouraged me through every journey. They have provided patience, loved me unconditionally, and helped me through every step I've taken. Without them, this process would have never come to a completion.

* Thank you is not enough to say to my wife, Rachel, and my three brilliant sons, Elliot, Noah and Ben. They are my four rocks. They are the reasons that I took on this challenge and completed it.

* Finally, without our Lord, God this journey would have never been made. 


\section{TABLE OF CONTENTS}

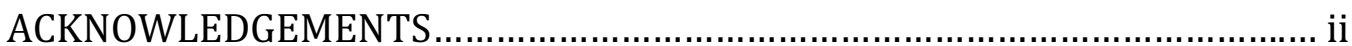

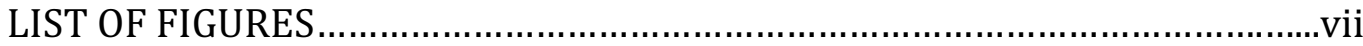

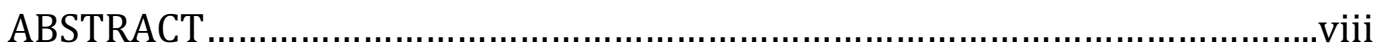

\section{CHAPTER}

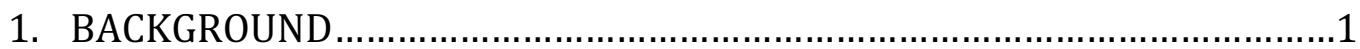

Conceptual Framework ...................................................................

Research Paradigm................................................................................

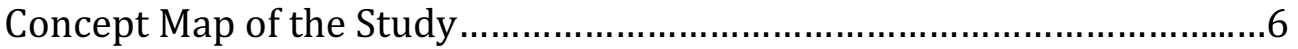

Review of Related Literature................................................................... 7

History of Special Education .............................................................

Principal's Role in Special Education ..............................................8

Preparation Programs for Principals ..............................................

Statement of the Problem.......................................................................... 11

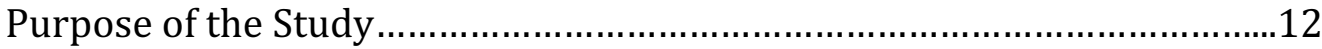

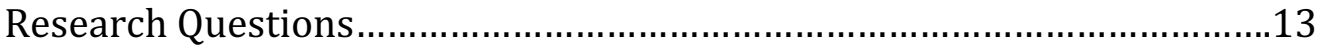

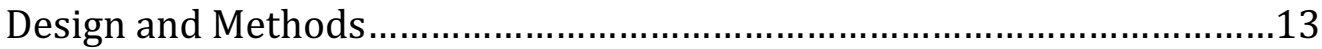

Limitations, Delimitations and Assumptions....................................... 15

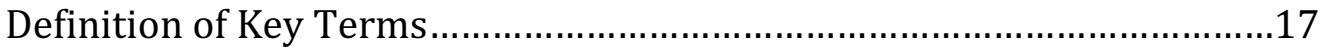

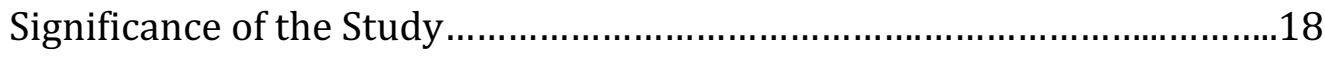

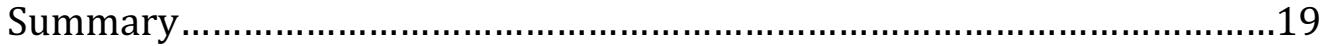

2. REVIEW OF RELATED LITERATURE ...................................................20

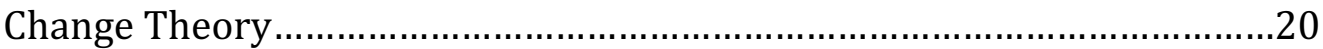


Public Education with Regards to Public Education................................22

Historical Perspective ..................................................................22

Recent Advancements..................................................................24

The Principal's Role in Special Education.............................................26

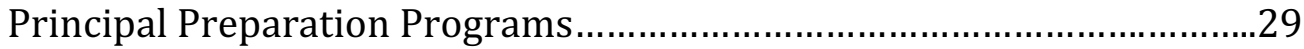

Early Graduate School Programs for Principals...............................29

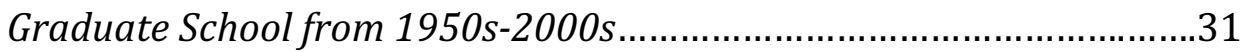

Current Programs for Principals ................................................33

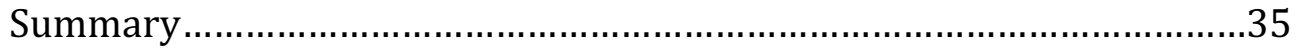

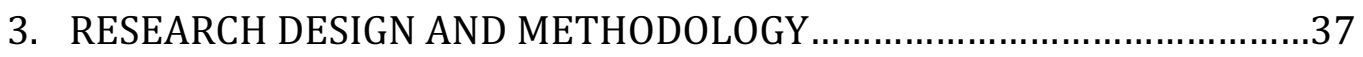

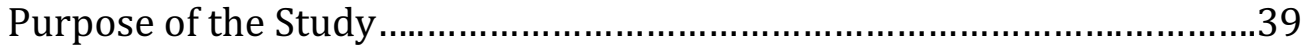

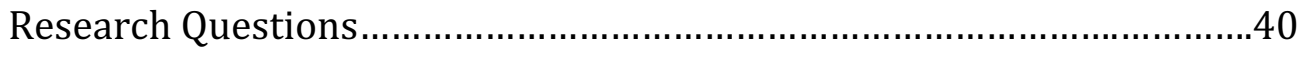

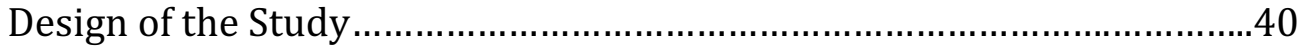

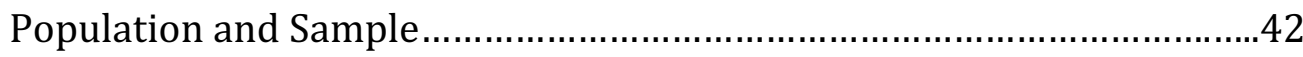

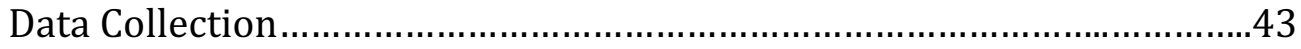

Data Collection Procedures..........................................................43

Interviews and Focus Group ....................................................44

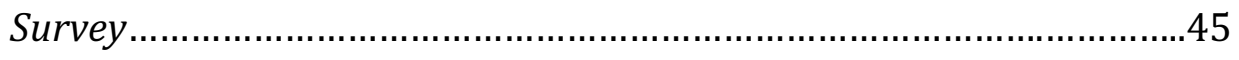

Human Subjects Protection ...........................................................45

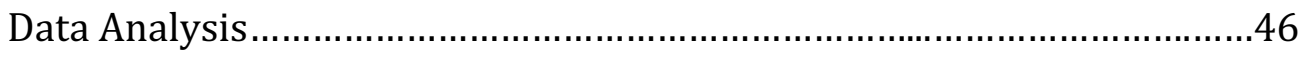

Qualitative Data Analysis............................................................ 46

Reliability and Validity ............................................................ 47 
Limitations, Delimitations, and Assumptions.................................4 47

Limitations........................................................................... 47

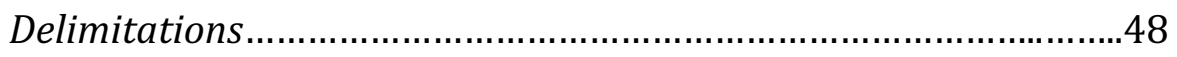

Assumptions ......................................................................48

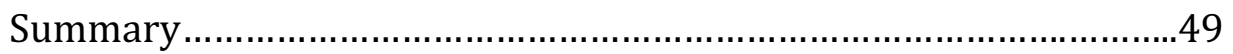

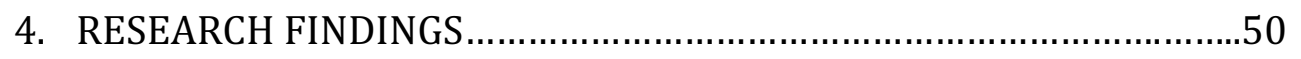

Setting for the Study ............................................................. 53

Relationship of Researcher to Research..................................54

Description of Participants.....................................................54

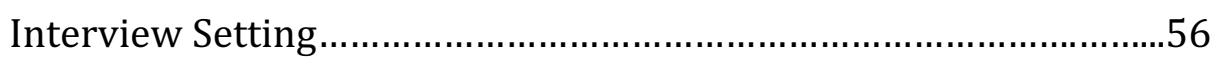

Interviews and Focus Group.................................................56

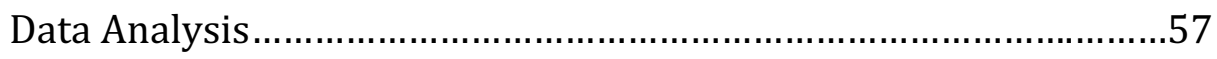

Findings from the Data......................................................5

Theme 1: The Organization of Special Education in a Building

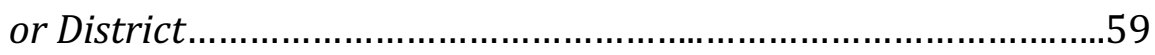

Theme 2: The Principal's Role in Special Education....................63

Theme 3: Training of Principals Regarding Special

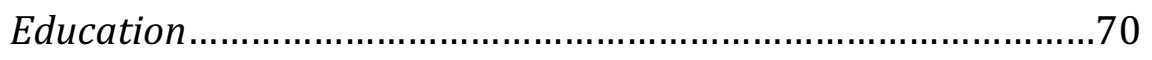

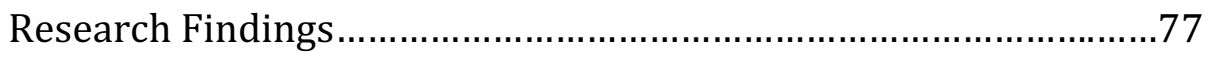

Strong Leadership in the Building ...........................................78

Creating More Time to Devote to Special Education.....................79

Dealing with Difficult Situations........................................... 80

Role of the Principal in the IEP Process.......................................81 


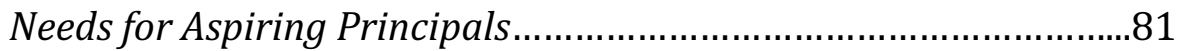

Answering the Research Questions...................................................

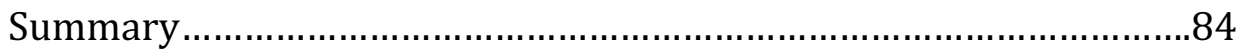

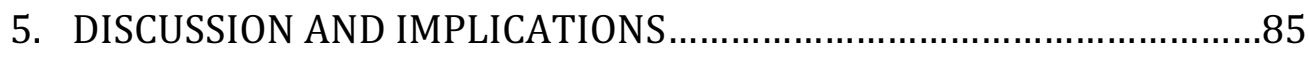

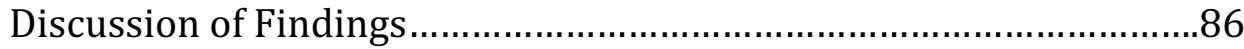

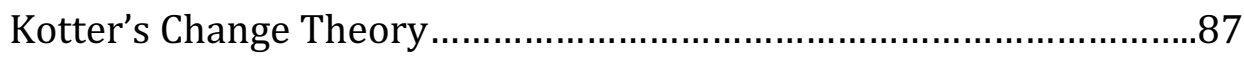

Impact of the Principal on Special Education Delivery ……................89

University Graduate Programs for Principals Regarding Special

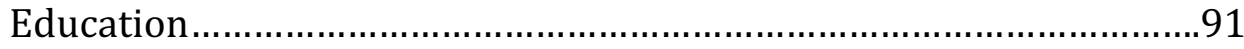

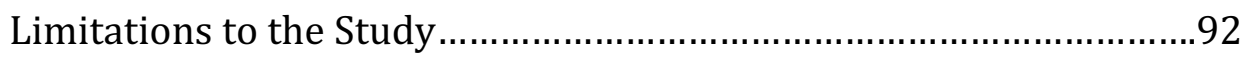

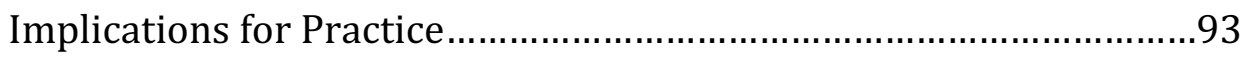

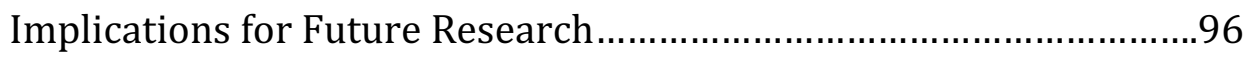

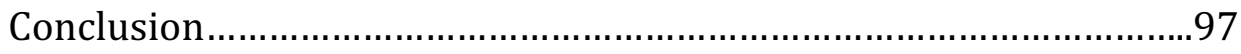

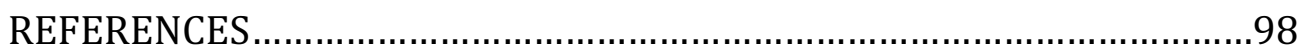

APPENDIXES

A. INFORMED LETTER OF CONSENT ……………………….......106

B. PRINCIPAL INTERVIEW QUESTIONS ...........................................109

C. FOCUS GROUP QUESTIONS ...................................................111

D. UNIVERSITY LEADER SURVEY ................................................113

E. VITA 


\section{LIST OF FIGURES}

1. Concept Map of Perceptions of Special Education Training as Viewed by Northwest Missouri High School Principals and Missouri University

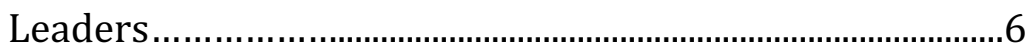




\section{PERCEPTIONS OF SPECIAL EDUCATION TRAINING AS VIEWED}

\section{BY NORTHWEST MISSOURI HIGH SCHOOL PRINCIPALS AND MISSOURI}

\section{UNIVERSITY LEADERS \\ Lucas (Luke) W. McCoy}

Dr. Carole Edmonds, Dissertation Supervisor

The purpose of this qualitative research project was to examine the perceptions of Northwest Missouri principals and university leaders from across the state of special education training that is received during principal preparatory graduate programs. A review of relevant literature gives background on the history of special education in the United States, the role of principals in special education, and a brief history on principal preparatory programs. Perceptions of principals regarding their own training revealed a lack of adequate preparation for leading in the area of special education. The researcher used a semi-structured interviews and focus group with principals in Northwest Missouri as well as on online survey for various university leaders. The interviews, focus group, and published courses of study from the universities produced data where three major themes evolved. The three themes included: (a) The Organization of Special Education in a Building or District, (b) The Principal's Role in Special Education, and (c) Training of Principals Regarding Special Education. Kotter's Change Theory was used to indicate a sense of urgency to make changes in how aspiring principals are trained regarding special education. 


\section{CHAPTER ONE}

\section{Background}

Educational leaders take on an extremely important role in the education of a child. Expectations of recruiting and mentoring new teachers, supervising an entire staff and student body, ensuring stakeholder communication, managing a sizable budget, school improvement planning, high stakes testing responsibilities, and nightly supervision obligations are just a handful of leader responsibilities that contribute to that education (Lynch, 2012). Factoring in the daily decision-making grind, the role of educational leaders is challenging to say the least. There is one responsibility, because of past and current legislation, that is just as important: The oversight of special education programming and compliance (Lynch, 2012).

The role of the principal has been historically viewed as a middlemanagement position that deals with budgeting, student discipline, rule making, facility decisions and the general management of teachers and students (Brazer and Bauer, 2013 and Wahlstrom, Louis, Leithwood and Anderson, 2010). That has largely changed because of the mandates from the No Child Left Behind Act of 2003 and again with the reissuance of Every Student Succeeds Act in 2016 (Roberts \& Guerra, 2017). States, school districts and individual schools are being held more accountable for all student achievement scores, college and career readiness, attendance, etc. which makes it imperative that exemplary leaders are in the role of building administrator (Rammer, 2007). The challenge of finding qualified candidates for administration who are instructionally sound, have the ability to motivate, can engage productively with stakeholders, and have a belief of shared 
leadership is one that hinders the progress of many districts and schools (Vanderhaar, Munoz, \& Rodosky, 2006). Finding quality candidates that have a deep understanding of special education law is almost impossible (McHatton, Boyer, Shaunessy, \& Terry, 2010).

Having the responsibility of LEA (Local Educational Agency) representative for special education purposes is one of the few opportunities in which costly mistakes could lead to severe repercussions to the student, building leader, school and district. Being part of IEP (Individualized education plan) teams, evaluating special education teachers and communicating with parents of students served by special education are all roles that principals or assistant principals could expect to take on. It is extremely important that the training received in becoming a principal provides the proper tools to effectively impact stakeholders in special education.

With over 6 million students nationwide receiving special education accommodations, one third being high school students, it is imperative that high school principals are properly prepared to make critical decisions regarding special education programs (Swanson, 2008). According to the Digest of Education Statistics (2015), developed by the U. S. Department of Education, Missouri has the $20^{\text {th }}$ highest percentage of total public school population being served with IEPs at $14.1 \%$. Based on past trends, it is unlikely that the number of students requiring special services will decrease. This will undoubtedly lead to high school administrators continuing to face challenges with decisions regarding staffing, evaluation of teachers, parental contacts, IEP team decision making and providing the needed leadership to the school for all students to be successful. 


\section{Conceptual Framework}

Researchers typically use a theoretical framework or theoretical lens when conducting qualitative research (Creswell, 2009). The framework of lens then shapes research by helping guide questions being asked, method of data collection and analysis, and how improvements or suggestions could be made. The conceptual framework for this study used Kotter's Change Theory, perceptions of principals of their graduate training regarding special education, their role in special education and the perceptions of college and university leaders regarding training that they offer.

\section{Change Theory}

In order to guide this study of principal experiences in special education and the programs that provide training for principals, a focus of change was determined to provide the best opportunity for improvement. Creswell (2009) suggests that using a theoretical lens helps provide the researcher a platform in order to form questions and how data could be used for change. The conceptual framework for this study included John Kotter's change theory as the theoretical lens to utilize the perceptions of principal's on their ability to adequately lead with specific regard to special education to promote change in training programs. Other framework pieces that were relied upon include the history of special education in the United States, the principal's role in special education, and graduate programs for principal preparation.

For a change to happen in how principals are trained, specifically in the area of special education, sound reasoning must be presented to university leaders. Kurt 
Lewin, a renowned social theorist, suggested a planned approach model of change, which involved unlearning old behavior, motivating new learning, and then stabilizing the new learning (Burnes, 2004). Other models, such as John Kotter's model, have framework related to Lewin's studies but present a more modern way of looking at changing the educational landscape. It also provides a lens that higher education leaders could use to promote special education training to future administrators.

Lewin's work primarily focused on social behavioral change that could help within a small or large organization (Burnes, 2004). While Lewin suggested that change would happen by "unfreezing, moving or transitioning, and refreezing" (1951), today's organizations possibly need more sophistication for needed change to occur. Kotter (1996) believes that in order for an organization to be successful, systematic change using his renowned 8 -step method is best. The 8 steps include: "Establishing a sense of urgency, creating the guiding coalition, developing a vision and strategy, communicating change vision, empowering employees for broad-based action, generating short-term wins, consolidating gains and producing more change, and anchoring new approaches in the culture." (Kotter, 1996)

Kotter's method has been widely regarded as an instrument that can be of use for a wide variety of organizations (Pollack \& Pollack, 2015). His process includes looking at differences between management and leadership, factoring in organizational weaknesses, and cultural obstacles to change (Kotter, 2006). It stands to reason that many universities suffer from similar obstacles as other 
organizations, thus using Kotter's work as a framework to funnel data found from this study will lead to higher education change with regards to principal preparation programs.

\section{Research Paradigm}

The researcher utilized a constructivist research paradigm, believing that interview and focus group participants have made interpretations of their experiences based on interaction with stakeholders in the environment in which they work (Creswell, 2009). The researcher intentionally engaged in open-ended questions throughout the interview and focus group process in order to allow participants opportunity to elaborate on their experiences. Creswell (2009) and Hatch (2002) suggest that using a constructivist paradigm allows participants to explain their views and form opinions based on their interactions. The interviews and focus group of principals and subsequent survey of university leaders were used to inform the researcher so that an inductive approach could be taken to generate possible solutions.

The following figure gives a visual representation of how the study flowed from one stage to the next: 


\section{Figure 1: Concept Map of the Study of Perceptions of Principals regarding Special}

\section{Education Training.}

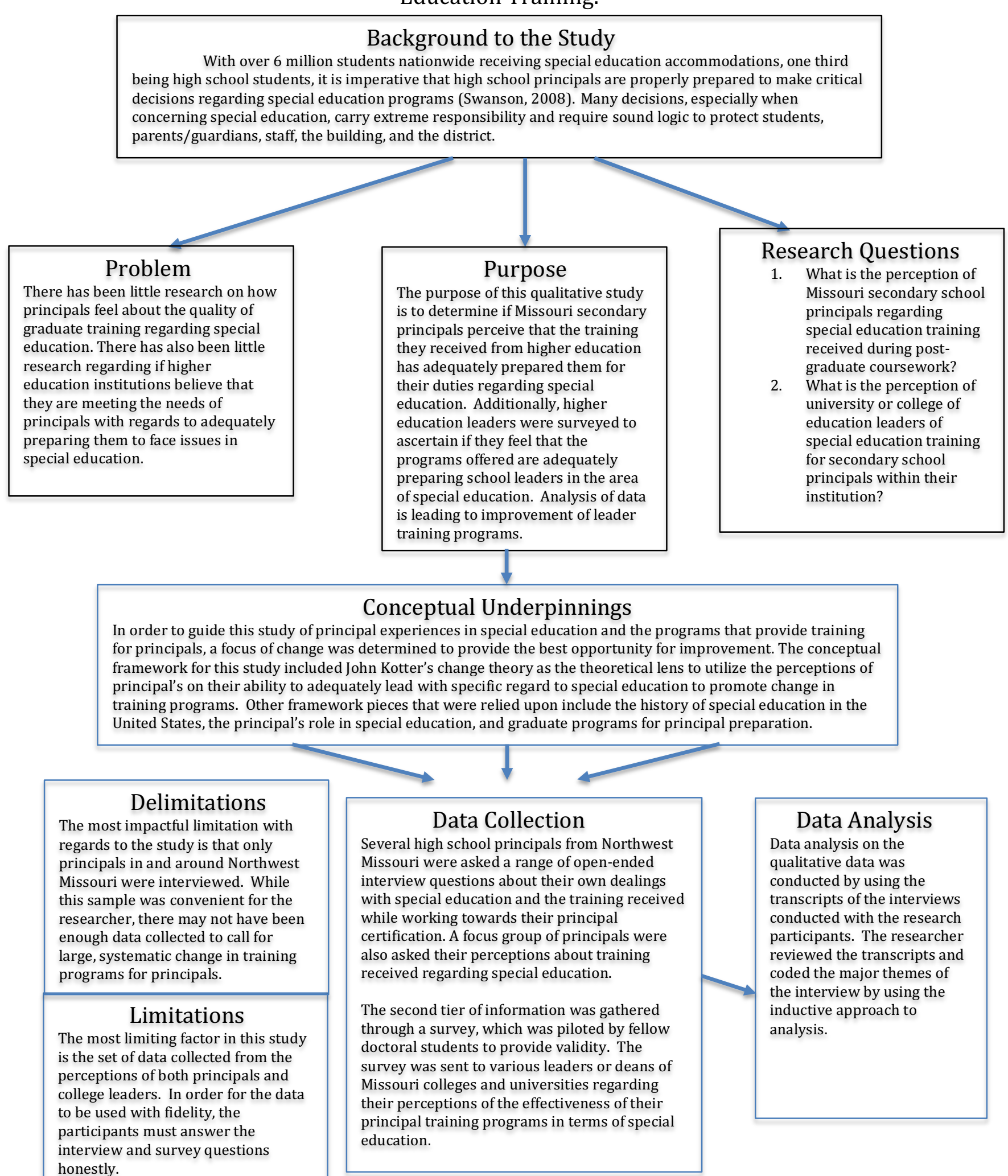




\section{Review of Related Literature}

\section{History of Special Education}

For almost 200 years, children that had educational delays or disabilities

were served sparsely. There were pockets of schools across the country that served deaf students and other exceptionalities, but most were not served in ways that met their individual needs. While the Brown v. Board of Education case in 1954 provided that separate accommodations are not equal and gave a platform for advocates of children with special needs, it did not specifically address special education (Kruger, 2004). Not until 1965, when President Lyndon Johnson signed into law the Elementary and Secondary Education Act (ESEA), did the US have a focus on giving educational opportunity to all students (US Department of Education, 2010). ESEA was promoted as a way to help students with disabilities, provide support to school libraries, and provide resources to low-income students. This act also helped provide funding for schools across the county for training of teachers with regards special needs and other resources to help the diverse population of students schools were housing (US Department of Education, 2010).

The ESEA provided a level of federal support for special education that had not been seen before, however schools continued to struggle helping those students who required the most support. Other legislative acts attempted to provide all students with a free and appropriate education. The Education of the Handicapped Act of 1970, Section 504 of the Rehabilitation Act of 1973, and the Education of All Handicapped Children Act of 1975 were all precursors to our current standards for serving students who need accommodations. In 1990, and again in 1997, the 
reauthorization of The Education for all Handicapped Children Act was passed by federal legislatures. It was renamed the Individuals with Disabilities Act (IDEA) and was essential in assuring that students with special needs would receive the services that they required in order to be academically successful (US Department of Education, 2010). Most recently, the reauthorization of ESEA in 2002, under the name the No Child Left Behind Act of 2001 (NCLB) was the biggest coup for those advocating that children with special needs would be expected to perform at levels comparable to regular education students (US Department of Education, 2016). Recently, new reform as signed into existence with the reauthorization of ESEA in 2015 under the name of Every Student Succeeds Act. This also puts specific emphasis on special education and how it is delivered in each school (US Department of Education, 2016).

\section{The Principal's Role in Special Education}

It is the principal's responsibility to oversee that students are provided with a free and appropriate education, which includes accommodations and the least restrictive environment possible for the success of all students with disabilities. It is their responsibility to provide oversight for inclusion of students with special needs, however many feel uncomfortable and ill prepared to do so (Cooner, Tochterman \& Garrison-Wade, 2005). Building principals help facilitate and make decisions that influence instruction for The No Child Left Behind Act of 2003 and the reissuance of the Individuals with Disabilities Education Act in 2004 have left school leaders to consider how special needs students can be included with general education 
students, yet maintain assessment scores that meet proficiency (Alvarez, Boyer, Shaunessy, \& Terry, 2010).

In order to ensure that the needs of all students are being met, the principal of a building must be properly trained. Throughout the country, a call for more urgency is being generated in providing rich training for principals at the university and school district level (Mchatton, Boyer, Shaunessy \& Terry 2010; Mitgang, 2012). At the same time, it has been documented that most administrators are poorly trained with respect to special education instruction (Lynch, 2012).

\section{Principal Preparation Programs}

It has been noted in various studies that the training of a building principal does have an effect on student achievement, therefore a commitment of collaboration between districts and local universities is important (Vanderhaar, Munoz, \& Rodosky 2006). Becoming a secondary school principal in the State of Missouri requires several steps, depending on an educator's background. The basic requirement from the Missouri Department of Elementary and Secondary Education is as follows:

"An Initial Administrator Certificate is the first certificate a new administrator receives. Completion of a master's degree or higher in educational administration from a college or university having an educational administration degree program approved by the Missouri Department of Elementary and Secondary Education is required. A superintendent certificate requires a minimum of an educational specialist degree. The applicant must have a recommendation for certification from 
the designated official for educational administration at the college or university where the program was completed. The applicant must also obtain Missouri's passing score on the appropriate assessments." (DESE, 2016) There are many universities that offer educational administration programs that satisfies the requirement of a master's degree or higher in the area of school leadership. However, according to Darling-Hammond, Lapointe, Meyerson, Orr, and Cohen (2007), "historically, initial preparation programs for principals in the U.S. have been a collection of courses covering general management principles, school laws, administrative requirements, and procedures, with little emphasis on student learning, effective teaching, professional development, curriculum, and organizational change." While some gains seem to have been made in the areas of curriculum and professional development, courses still tend to be management focused.

While special education curriculum may be embedded within some coursework, there are few stand-alone courses offered to prepare aspiring principals for the ever-rising special education population. At Missouri State University, a course named Administration of Special Programs is required for master's level work in educational administration. The course description reads, "designed to provide skills to establish, administer and supervise special education services and other student programs. Programs in the area of special education, guidance, vocational education, early childhood as well as current state and federal programs affecting education are emphasized" (Missouri State University, 2017). 
While the course looks to provide some special services instruction, it may only be a small piece of the course.

\section{Statement of the Problem}

There is a gap between the training of secondary principals and the expectations placed on principals regarding special education (McHatton, Boyer, Shaunessy, \& Terry, 2010). In order for a leader to make sound decisions regarding special education issues, he or she must have staff members in which one could rely on in the process of making decisions, but must also have the schema in which to base his/her opinions. It is of utmost importance for two reasons: a child's education may hinge on those decisions and a poor decision puts the school and the district at risk because of non-compliance to special education law.

It stands to reason that informed leaders make decisions of higher quality. It also makes sense that if the needs of Missouri's principals are not thoroughly communicated to leaders of higher education, one would not expect to gain the training needed to become successful in leading a school. The disconnect between knowledge needed by leaders and training received regarding special education is pivotal because of the continual cloud of lawsuit and, more importantly, properly educating each and every child that attends a public school institution. McHatton, Boyer, Shaunessy and Terry (2010) drive home two points regarding the importance of this issue: Principals are heavily involved with special education issues and district professional development provides more information than preservice principal preparation programs. If this is indeed the case, a closer look at how universities handle special education training is needed. 


\section{Purpose of the Study}

It is estimated that school districts will replace up to $60 \%$ of building principals within the next five years (Peterson, 2002). This makes it imperative that new principals have the needed skills, in all areas, to lead their school instructionally and operationally. The purpose of this qualitative study is to determine if Missouri secondary principals perceive that the training they received from higher education has adequately prepared them for their duties regarding special education. High School principals were interviewed, with questions created by the researcher, focusing on their perceptions of leader training programs with regards to special education training. A focus group of high school principals were also asked questions regarding their perception about training received dealing with special education. Additionally, higher education leaders were surveyed to ascertain if they feel that the programs offered are adequately preparing school leaders in the area of special education. Triangulation of data and subsequent analysis may point to needed changes to principal training programs.

Special education is a diverse field, thus participants only answered questions based upon services to children with learning or behavioral disabilities. Gifted students, students accessing 504 accommodations, and alternatively placed students are not covered in the scope of this study. Data gathered will be used to make recommendations to Missouri universities for pre-service principal preparation programs using theory ideas supported by Kurt Lewin and modern change theorists such as John Kotter as well as add to the body of work related to principal preparedness. 


\section{Research Questions}

The following two research questions guide this qualitative study as to bridge a potential gap in secondary school principal's knowledge of special education and what universities provide in their graduate coursework.

1. What is the perception of Missouri secondary school principals regarding special education training received during post-graduate coursework?

2. What is the perception of university or college of education leaders of special education training for secondary school principals within their institution?

\section{Design and Methods}

Qualitative procedures were used to gather data for this study. According to John Creswell (2009), qualitative procedures for data collection focuses on multiple sources of data collection, natural setting, participants meaning, theoretical lens and interpretive inquiry. In qualitative research the researcher plays a very active role in gathering information for the study. With regards to this study, the researcher focused on interviews, focus groups, surveys, and review of documents and artifacts to conduct research. Because two distinct groups were targeted and focused stream of data was generated, the sample population would be considered purposive or selective (Creswell, 2009).

Several high school principals from Northwest Missouri were asked a range of open-ended interview questions about their own dealings with special education and the training received while working towards their principal certification. While this is a sample of convenience because of the proximity of the participants, it allows for essential information in a timely manner (Cresswell, 2009). A focus group of 
high school principals were also invited by the researcher to take part in a focus group that would gather data on perceptions of training with regards to special education.

The second tier of information was gathered through a survey, which was piloted by fellow doctoral students to provide validity. The survey was sent to various leaders or deans of Missouri colleges and universities regarding their perceptions of the effectiveness of their principal training programs in terms of special education. Analysis of the data through change theory will ultimately lead to improvement of leader training programs.

The researcher also gained access to a variety of documents and artifacts from Missouri universities that outline coursework that an educational leader would expect to take during the preparation program. This includes course listings and curriculum for courses that are offered in conjunction with a graduate degree program.

Data analysis on the qualitative data was conducted by using the transcripts of the focus group and interviews conducted with the research participants. The researcher reviewed the transcripts and coded the major themes gathered from participant answers by using the inductive approach to analysis. The inductive approach means "the data are read searching for particulars that can be put into categories because of their relation to other particulars" (Hatch, 2002; p. 164). By coding the data individually and determining themes the researcher was able to triangulate the data (Hatch, 2002). The general themes are reported in the findings section. 
Because special education is such a diverse field, participants only answered questions based upon services to children with learning or behavioral disabilities. Gifted students, students accessing 504 accommodations, and alternatively placed student issues are not covered in the scope of this study.

\section{Limitations, Delimitations and Assumptions}

\section{Limitations}

The most limiting factor in this study is the set of data collected from the perceptions of both principals and college leaders. In order for the data to be used with fidelity, the participants must answer the interview and survey questions honestly.

According to Dillman, Smyth, and Christian (2009) using internet based surveys introduce difficulties with participant response. They argue that because there is little personal attention given to participants, the propensity to delete emails and a minute amount of time investment between researcher and participant it is often difficult to generate response from the given sample (Dillman, Smyth \& Christian, 2009). This may have limited the number college leaders to take part in the research.

\section{Delimitations}

Using a convenience sample for the qualitative portion of the study is less desirable than using other types of sample according to Hatch (2002). The most impactful limitation with regards to the study is that only principals in and around Northwest Missouri were interviewed. While this sample was convenient for the 
researcher, there may not have been enough data collected to call for large, systematic change in training programs for principals. Another delimitation is the topic of the study itself, which implies that principals needed more instruction on the issues with regards to special education.

\section{Assumptions}

The first assumption being made in this study is that all principals have interactions with special education services. While it is likely that each school has a special education department of some form, it could be that each principal at a school has varying roles concerning special education. As noted previously, the assistant principal position can be somewhat vague in terms of job requirements and special education may or may not be included in their assignments (Kwan, 2009). While it is impossible to know the extent of duties before extending interview requests, the researcher assumed that the leaders have knowledge regarding special education in their building.

The second assumption that is being made with regards to this study is that the dean or supervisors for the college of education at various schools has working knowledge about the curriculum offered in graduate courses and will give honest feedback regarding course offerings. There could be difficulty in gathering data regarding their perceptions because they want to communicate a positive message regarding their institution. It took much thought in developing the interview questions so as to build a feeling of trust between the participant and researcher (Hatch, 2002). 
In doing qualitative research, the researcher introduced opportunity for personal bias. The researcher feels there was insufficient training with regards to adequately understanding the scope of special education. Multiple decisions dealing with special education have been made in which the researcher felt not fully prepared to make. It was critical that when interviewing the various participants that the researcher maintain neutrality when asking questions and that the upmost respect be given to each university (Hatch, 2002).

\section{Definition of Key Terms}

The following terms are used during the writing of this research study.

\section{Individualized Education Program (IEP):}

An individualized education program (IEP)is the legal documentation for a child's education based on his/her disability. It contains objectives and accommodations that are to be made in order to help the student be successful as determined by the IEP team.

\section{IEP Team:}

Typically an IEP team will consist of a teacher (or several teachers), a special education teacher (or several teachers), the LEA representative, the parent(s) of the child receiving special services, and the student (when appropriate). Other professionals that have working knowledge of the particular disability may also sit on the team when appropriate and needed. 


\section{Graduate training coursework:}

Graduate training coursework refers to graduate courses taken in masters, specialist or doctoral programs that participants have enrolled in to further their education in an effort to become a school administrator.

\section{No Child Left Behind Act of 2001 (NCLB):}

Signed into law in 2002, the NCLB Act of 2001 put into place the expectation of educational improvement for all students, regardless of race, gender, socioeconomic status or special needs. The law, which will soon be up for reauthorization, is ultimately tied to each state's accreditation.

\section{Special education:}

Special education refers to all areas of educating students who have a documented disability which causes a disruption in learning.

\section{Significance of the Study}

It is estimated that school districts will replace up to $60 \%$ of building principals within the next five years (Peterson, 2002). This makes it imperative that new principals have the needed skills, in all areas, to lead their school instructionally and operationally. Higher education and PK-12 public schools are partners in growing leaders, so it would make sense that data from both parties be analyzed to see if outcomes are matching training goals for aspiring principals. The researcher is hopeful that this study will open up new opportunities in training prospective high school administrators. School leaders are faced with daunting challenges at times and with the proper training they can make informed decisions that will have positive influence on students, staff and the community being served. 
In order for change to occur in the public school system and at the higher education data must be presented in a way that is meaningful and impactful (Kezar, 2013).

\section{Summary}

"Effective administrators need to develop a working knowledge about disabilities and the unique learning and behavioral challenges various conditions present" (DiPaola \& Walther-Thomas, 2004, p. 11).

The principal at every high school seemingly makes hundreds of decisions every day. Many decisions, especially when concerning special education, carry extreme responsibility and require sound logic to protect students, parents/guardians, staff, the building, and the district. There has been little research on how principals feel about the quality of graduate training regarding special education. There has also been little research regarding if higher education institutions believe that they are meeting the needs of principals with regards to adequately preparing them to face issues in special education.

In this qualitative study, interviews and a focus group of high school principals were used to detail perceptions of the special education training received in graduate classes. Deans of colleges of education at several Missouri universities were also surveyed to gain other data to analyze if they perceive the needs of principals are being met regarding special education training. The sets of data were used to devise recommendations for changes in current programming at Missouri universities regarding special education training given to aspiring principals. 


\section{CHAPTER 2}

\section{Review of Related Literature}

School systems seemingly want to lead with innovative change. Whether it is with technology, professional development or assessment, school leaders have been challenged to find ways to reach the needs of students. The lack of leader specific training, however, has oftentimes been the demise of well intentioned projects and programs. Special education programs are no different. Lack of training for school leaders regarding special education has hamstrung even the most basic services, let alone expanding services to reach a growing special services population (Cooner, Tochterman \& Garrison-Wade, 2005).

Bringing change to the way school leaders are trained requires looking at how the job has changed over time and what is needed in the current culture of leadership. Being a manager of a school is no longer sufficient in order to help meet the needs of a rapidly changing educational landscape (Angelle \& Bilton, 2009). A leader must be able to invoke systematic change and work with all stakeholders in order to make change possible. In order to do that, the correct training must be occurring at our colleges and universities to give leaders the the tools the need, including being able to meet the needs of all students.

\section{Change Theory}

For a change to happen in how principals are trained, specifically in the area of special education, sound reasoning must be presented to university leaders. Kurt Lewin, a renowned social theorist, suggested a planned approach model of change, which involved unlearning old behavior, motivating new learning, and then 
stabilizing the new learning (Burnes, 2004). Other models, such as John Kotter have framework related to Lewin's studies, but present a more modern way of looking at changing the educational landscape and provides a lens that higher education leaders could use to promote special education training to future administrators.

Lewin's work primarily focused on social behavioral change that could help within a small or large organization (Burnes, 2004). While Lewin suggested that change would happen by "unfreezing, moving or transitioning, and refreezing" (1951), today's organizations possibly need more sophistication for needed change to occur. Kotter (1996) believes that in order for an organization to be successful, systematic change using his renowned 8-step method is best. The 8 steps include: "Establishing a sense of urgency, creating the guiding coalition, developing a vision and strategy, communicating change vision, empowering employees for broad-based action, generating short-term wins, consolidating gains and producing more change, and anchoring new approaches in the culture." (Kotter, 1996)

Kotter's method has been widely regarded as an instrument that can be of use for a wide variety of organizations (Pollack \& Pollack, 2015). His process includes looking at differences between management and leadership, factoring in organizational weaknesses, and cultural obstacles to change (Kotter, 2006). It stands to reason that many universities suffer from similar obstacles as other organizations, thus using Kotter's work as a framework to funnel data found from this study will lead to higher education change with regards to principal preparation programs. 


\section{Public Education with Regards to Special Services}

\section{Historical Perspective}

Thomas Jefferson was the founding father of the American educational system in the late $18^{\text {th }}$ Century, but it wasn't until almost 100 years later that the Federal Department of Education was founded. It was reported that about 7 million students were enrolled in elementary grades and over 80,000 in secondary grades (Ravitch, 2000). By 1890, close to $95 \%$ of children eligible to attend an elementary school were enrolled, however only $5 \%$ of students moved on to high school (Ravitch, 2000). Fast forward to 2017, and one can easily see that the landscape of public education has changed tremendously in many areas, especially with regards to students who need additional supports.

For almost 200 years, children that had educational delays or disabilities were served sparsely. There were pockets of schools across the country that served deaf students and other exceptionalities, but most were not served in ways that met their individual needs (U.S. Department of Education, 2010). While the Brown v. Board of Education case in 1954 provided that separate accommodations are not equal and gave a platform for advocates of children with special needs, it did not specifically address special education. Not until 1965, when President Lyndon Johnson signed into law the Elementary and Secondary Education Act (ESEA), did the US have a focus on giving educational opportunity to all students. ESEA was promoted as a way to help students with disabilities, provide support to school libraries, and provide resources to low-income students. This act also helped provide funding for schools across the county for training of teachers with regards 
special needs and other resources to help the diverse population of students schools were housing (US Department of Education, 2010).

While ESEA provided a level of federal support for special education that had not seen before, schools continued to struggle helping those students who required the most support. Not long after ESEA had been approved, states still had numerous institutions that housed children with special needs which only provided basic needs and very little educational support (US Department of Education, 2010). According the US Department of Education, "in 1970, U.S. schools educated only one in five children with disabilities, and many states had laws excluding certain students from school, including children who were deaf, blind, emotionally disturbed, or mentally retarded" (p. 3, 2010). It was clear that more local support was needed in order to educate all children in a fashion that would promote future success.

Several other legislative acts attempted to provide all students with a free and appropriate education. The Education of the Handicapped Act of 1970, Section 504 of the Rehabilitation Act of 1973, and the Education of All Handicapped Children Act of 1975 were all precursors to our current standards for serving students who need accommodations. Prior to the 1975 Act, children with disabilities were often taught in centers or in schools outside of the student's school district. These students were oftentimes placed in an alternative setting, with alternative supervision, that didn't include training teachers or principals (Lashey, 2007). With the passage of The Education for all Handicapped Children Act, students who were recognized with a specific learning disability were eligible for 
services for their unique disability (Singer \& Butler, 1987). The provisions of this act also changed the principal's role dramatically with regards to responsibilities in servicing students with disabilities. While school districts still placed the additional responsibilities on the plates of district level special education staff members, principals had to begin adapting to the needs of students who needed extra supports (Lashley, 2007).

\section{Recent Advancements in Federal Education Acts}

In 1990, and again in 1997, the reauthorization of The Education for all Handicapped Children Act was passed by federal legislatures. It was renamed the Individuals with Disabilities Act and was essential in assuring that students with special needs would receive the services that they required in order to be academically successful. LRE, which stands for least restrictive environment was introduced during this time and schools were charged with providing services that would allow special education students to reach goals set forth by the parents, student, and the rest of the IEP team (U.S. Department of Education, 2002). Particular attention was given to the least restrictive environment provision as it was deemed instrumental in providing for and protecting special services students with regards to the regular education environment (U.S. Department of Education, 2002).

ESEA was reissued in 1994, billed as the Improving America's Schools Act (IASA) which focused on creating high standards for students, teacher training, accountability and local reform, and collaboration between all stakeholders in the local community (US Department of Education, 1995). According to the US 
Department of Education (1995) the effort was "designed to support states, districts, and schools as they work to ensure that all children in America reach challenging academic standards." (p. 11). The use of the word "all" strengthened the ability of advocates of those with special needs to demand the opportunity to hold schools accountable for those students' education.

The reauthorization of ESEA in 2002, under the name the No Child Left Behind Act of 2001 (NCLB) was the biggest coup for those advocating that children with special needs would be expected to perform at levels comparable to regular education students. States were charged with closing gaps in achievement for all students, including those living in poverty, those from varying ethnic and cultural backgrounds, and those students requiring special education to meet educational needs. Along with the reauthorization of ESEA, changes in IDEA were made to better align with current specifications with regards to students with disabilities. One such revision was that those students served in a private or parochial school would be served by the local public LEA, which leads to a stretch of services provided by public institutions (Colarusso \& O’Rourke, 2006).

ESEA was reauthorized in 2015 by President Obama, naming it Every Student Succeeds Act (ESSA). This act requires states to be in compliance in many areas of special education, including learning standards, assessment, IEP goal setting, graduation, accountability and bullying/harassment (Council of Chief State School Officers, 2016). Though the Council of Chief State School Officers (2016) paint a broad picture of how the new guidelines by ESSA will impact special education is delivery to all schools, in the least schools must begin to better align 
special education courses with regular education curriculum and assess all students to show proficiency levels.

While strides have been made with regards to giving access to students with special educational needs, there are still disturbing gaps in graduation rates and state assessment achievement levels between regular education students and those that require special services. According to Ulrich Boser (2009), close to 25\% of special education students drop out of high school without earning a high school diploma with those who have specific learning disabilities and emotional disturbances dropping out with higher frequency.

\section{The Principal's Role in Special Education}

Educational leaders take on an extremely important role in the education of a child. Expectations of recruiting and mentoring new teachers, supervising an entire staff and student body, ensuring stakeholder communication, managing a sizable budget, school improvement planning, high stakes testing responsibilities, and nightly supervision obligations are just a handful of leader responsibilities that contribute to that education (Lynch, 2012). Factoring in the daily decision-making grind, the role of educational leaders is challenging to say the least. There is one responsibility, because of past and current legislation, that is just as important: The oversight of special education programming and compliance (Lynch, 2012).

The role of the principal has been historically viewed as a middlemanagement position that deals with budgeting, student discipline, rule making, facility decisions and the general management of teachers and students (Brazer \& Bauer, 2013 and Wahlstrom, Louis, Leithwood \& Anderson, 2010). That has largely 
changed because of the mandates from the No Child Left Behind Act of 2002. States, school districts and individual schools are being held more accountable for all student achievement scores, college and career readiness, attendance, etc. which makes it imperative that exemplary leaders are in the role of building administrator (Rammer, 2007). The challenge of finding qualified candidates for administration who are instructionally sound, have the ability to motivate, can engage productively with stakeholders, and have a belief of shared leadership is one that hinders the progress of many districts and schools (Vanderhaar, Munoz, \& Rodosky, 2006). Finding quality candidates that have a deep understanding of special education law is almost impossible (Alvarez, Boyer, Shaunessy, \& Terry, 2010).

Principals are expected to be able to speak to instruction, curriculum, assessment, and evaluations, but they are also expected to be able to speak to the legal aspects of the rights of special education students and families (McHatton, et al. 2010). Building principals need to be properly equipped to help facilitate and make decisions that influence instruction for not only regular education teachers, but those who teach special education as well. Having the responsibility of LEA (Local Educational Agency) representative for special education purposes is one of the few opportunities in which costly mistakes could lead to severe repercussions to the student, building leader, school and district. Being part of IEP (Individualized education plan) teams, evaluating special education teachers and communicating with parents of students served by special education are all roles that principals or assistant principals could expect to take on. It is extremely important that the 
training received in becoming a principal provides the proper tools to effectively impact stakeholders in special education.

It is the principal's job to oversee that students are provided with a free and appropriate education, which includes accommodations and the least restrictive environment possible for the success of all students with disabilities (Lynch, 2012). It is their responsibility to provide oversight for inclusion of students with special needs, however many feel uncomfortable and ill prepared to do so (Cooner, Tochterman \& Garrison-Wade, 2005). The No Child Left Behind Act of 2003 and the reissuance of the Individuals with Disabilities Education Act in 2004 have left school leaders to consider how special needs students can be included with general education students, yet maintain assessment scores that meet proficiency (Alvarez, Boyer, Shaunessy, \& Terry, 2010).

In order to ensure that the needs of all students are being met, the principal of a building must be properly trained. Throughout the country, a call for more urgency is being generated in providing rich training for principals at the university and school district level (Mchatton, Boyer, Shaunessy \& Terry 2010; Mitgang, 2012). McHatton, et all (2010) also say that research has shown that many training programs are not providing the necessary relevant fundamental practice training, rather a more theory based approach. At the same time, it has been documented that most administrators are poorly trained with respect to special education instruction (Lynch, 2012).

A survey of principals by Laskey and Karge (2006) found that over $75 \%$ of principals felt ill-prepared to deal with issues surrounding special education, yet 
more time is devoted daily by leaders to special education than years past (Lynch, 2012). Angelle and Bilton (2009) also contend that "most principals lack any background from coursework and field experience which may be required to exert strong leadership in special education" (p. 5). They had also noted that $25 \%$ of principals indicated that they had received no internship hours devoted to special education issues in their programs (Angelle \& Bilton, 2009).

The risks associated with special education, combined with the uncertainty of not be properly trained, can impact a leader's ability to perform the necessary tasks of a modern educational leader (Angelle \& Bilton, 2009). Combining this risk and uncertainty with an August 2016 report from the US Department of Education, Office of Postsecondary Education, showing Missouri had significant teacher shortages especially with regards to special education, in which were submitted for federal grant help (U.S. Department of Education, 2016). In particular, Special Education teachers were reported by the state to have been in a shortage for the past 25-30 years.

\section{Principal Preparation Programs}

\section{Early Graduate School Programs for Principals}

During the early 1800 's, where schools were mostly rural in nature and not likely being influenced by strong state or federal departments of education, school leaders were typically non-professionals who attempted to gain local support for educating children (Tyack \& Hansot, 1982). The norm would be for the leaders, or head teacher, to stress the importance of Christianity and the role the school could play in being an extension of church teachings. They would also be cognizant of the 
economy and inform the public on how the school can improve the capitalist interests of the United States, under the guidance of a local organization board (Rousmaniere, 2007; Tyack \& Hansot, 1982,). There were a few urban school districts in the nation that needed a head administrator because of the growth of the schools and the need to divide the schools into grades or achievement levels. They would typically administer discipline, supervise teachers and organize the structure of the school (Rousmaniere, 2007). These leadership positions did not require extra schooling to attain, they were filled mostly due to need and given to experienced teachers, regardless of gender.

As the turn of the $20^{\text {th }}$ century unfolded, prior to university led principal preparation programs, "principals" were typically teachers with added responsibilities or the teacher in a one-room schoolhouse. In urban areas, however, the principal position began taking shape. Rousmaniere (2007) claims there was major shift from the mundane tasks such as running the furnace to more leadership opportunities such as setting culture and being more prominent in the community. The shift in responsibilities for a principal also ushered in the beginning of preparation programs for principals.

From 1923 until the early 1950's one third of state education departments required principals to be certificated by a preparation program. These programs would differentiate between teacher preparation programs, principal training, as well as differentiation between central office administrators (Rousaniere, 2007). During World War II and for years after, the expectation of the principal was to uphold patriotic values and enhance the sense of a strong community which was 
typically part of the principal's training (Andrews \& Gogan, 2002). During this time, concepts such as curriculum, teacher supervision and school climate were also thought of as important training points for aspiring principals (Tyrack \& Hansot, 1982).

\section{Graduate School from 1950-2000s}

From the 1950's to the 1980's social changes that came about because of events such as Brown v. Board of Education of Topeka and signing of the Elementary and Secondary Education Act signed by President Lyndon Johnson, the United States began to focus on giving educational opportunity to all students, thus again requiring changes in principal preparation programs (Tyack \& Hansot, 1982). Public schools were now much more inclusive of those with special needs, students who were socioeconomically disadvantaged and minority students, which required a different skill set for a principal. Cooper \& Boyd (1987) suggested that graduate programs, in order to meet those varied needs, began to incorporate more social science, leadership courses, school law, budgeting and finance. By the end of this period, however, according to Murphy (2003) "the profession as a whole, up to this time complacent began to stir," which leads to the next phase of professional development of principals.

In the late 80 's and into the 90 's, principal preparation programs began shifting from a management training approach to training principals how to be instructional leaders and change agents (Andrews \& Gogan, 2002). With the reissuance of ESEA in 1994 and subsequent initiatives such as No Child Left Behind in 2001, there became more pressure put on programs to help principals adjust to 
the changing educational climate. These pressures led to leadership standards being created by the Interstate School Leaders Licensure Consortium in 1996 and revised in 2008. Murphy (2003) suggests that the new standards help guide principals to be an "educational leader who promotes the success of all students by facilitating the development, articulation, implementation, and stewardship of a vision of learning that is shared and supported by the school community" (p. 42). The most recent leadership standards, Professional Standards for Educational Leaders, was adopted in 2015. They are a research-based set of 10 standards which the National Policy Board for Educational Administration (2015) says:

Have been recast with a stronger, clearer emphasis on students and student learning, outlining foundational principles of leadership to help ensure that each child is well-educated and prepared for the $21^{\text {st }}$ century. They elevate areas of educational areas of educational leader work there were once not well understood or deemed less relevant but have since been shown to contribute to student learning" (p. 2).

With the reauthorization of the 50 year ESEA, signed by President Obama on December 10 $0^{\text {th }}, 2015$ under the name Every Student Succeeds Act (ESSA) even more pressure was put on leaders to tackle the success of every student regardless of ability level (US Department of Education, 2016). The combination of these measures means that it is even more imperative that districts work with colleges and universities to deploy principal preparation programs that meets the needs of 
an ever changing leadership landscape (Brazer \& Bauer, 2013; National Policy

Board for Educational Administration, 2015)

\section{Current Preparation Programs for Principals}

It has been noted in various studies that the training of a building principal does have an effect on student achievement, therefore a commitment of collaboration between districts and local universities is important (Vanderhaar, Munoz \& Rodosky, 2006). Becoming a secondary school principal in the State of Missouri requires several steps, depending on an educator's background. The basic requirement from the Missouri Department of Elementary and Secondary Education is as follows:

An Initial Administrator Certificate is the first certificate a new administrator receives. Completion of a master's degree or higher in educational administration from a college or university having an educational administration degree program approved by the Missouri Department of Elementary and Secondary Education is required. A superintendent certificate requires a minimum of an educational specialist degree. The applicant must have a recommendation for certification from the designated official for educational administration at the college or university where the program was completed. The applicant must also obtain Missouri's passing score on the appropriate assessments. (DESE, 2014)

There are many universities that offer educational administration programs that satisfies the requirement of a master's degree or higher in the area of school leadership. However, according to Darling-Hammond, Lapointe, Meyerson, Orr, and 
Cohen (2007), "historically, initial preparation programs for principals in the U.S. have been a collection of courses covering general management principles, school laws, administrative requirements, and procedures, with little emphasis on student learning, effective teaching, professional development, curriculum, and organizational change." While some gains seem to have been made in the areas of curriculum and professional development, courses still tend to be management focused. For example, Northwest Missouri State University in Maryville, MO offers a graduate program for Educational Leadership - Secondary, which requires courses such as School Finance, School Law, School Supervision, Secondary School Curriculum, Technology for School Administrators, Philosophy in Education, and Improvement of Instruction Through Action Research. Likewise, a search of the University of Missouri's College of Education PK-12 Leadership and Policy Master's Degree program found that the topics covered centered around the following: databased decision making, school improvement, curriculum leadership, providing professional development, finance and law, and politics of school leadership. While courses dealing with assessment, instruction and professional development are absolutely needed (Brazer \&Bauer, 2013), there is no mention of the responsibilities educational leaders face with specific regards to special education programming and law.

While special education curriculum may be embedded within some coursework, there are few stand-alone courses offered to prepare aspiring principals for the ever-rising special education population. At Missouri State University, a course named Administration of Special Programs is required for 
master's level work in educational administration. The course description reads, "designed to provide skills to establish, administer and supervise special education services and other student programs. Programs in the area of special education, guidance, vocational education, early childhood as well as current state and federal programs affecting education are emphasized." (Missouri State University, 2017). While the course looks to provide some special services instruction, it may only be a small piece of the course.

According to Murphy (2003), an expert on school leader standards, a typical masters of school administration will include courses such as, "business administration, personnel administration, organizational theory, school finance, supervision of employees, and school facilities" (p. 41). Rarely is special education mentioned in the programming literature. The importance of special education law and instruction needs to be emphasized in order for a principal to be ready for the new challenges that the principalship requires (Murphy, 2003).

\section{Summary}

Programs for the training of educators to become principals have evolved greatly over the past 100 years. Being focused on the management side of the principalship, which looks at the school as a business, has given way to instructional leadership and relationship building with all stakeholders. The idea of what a principal should focus on has also evolved over time, especially in regards to legal aspects of special education. While that has become a topic of great concern, little has changed in the way principals are trained regarding special education. In order for a change to occur, the perceptions of principals must be shared with higher 
education leaders in order to create a sense of urgency for changes in how principals are prepared (Kotter, 1996). 
CHAPTER THREE

\section{RESEARCH DESIGN AND METHODOLOGY}

With over 6 million students nationwide receiving special education accommodations, one third being high school students, it is imperative that high school principals are properly prepared to make critical decisions regarding special education programs (Swanson, 2008). According to the Digest of Education Statistics, which is developed by the U. S. Department of Education, Missouri has the $20^{\text {th }}$ highest percentage of total public school population being served with IEPs at $14.1 \%$ (2011). It is unlikely that the number of students requiring special services will decrease based on past trends which means high school administrators will continue to face challenges with decisions regarding staffing, evaluation of teachers, parental contacts, IEP team decision making and providing the needed leadership to the school for all students to be successful.

It is the principal's job to oversee that students are provided with a free and appropriate education, which includes accommodations and least restrictive environment for the success of all students with disabilities (Mitgang, 2012). In order to ensure that the needs of all students are being met, the principal of a building must be properly trained. Throughout the country, a call for more urgency is being generated in providing rich training for principals at the university and school district level (Mitgang, 2012).

Extensive training is also addressed in other studies, which ties special education law, the reauthorization of No Child Left Behind and extreme principal turnover to problems arising with special education (Pallodino, 2008 \& Cooner, 
Tochterman \& Garrison-Wade, 2005). The alignment of special education and regular education is becoming closer and closer and more training is needed regardless of years served as an assistant principal or head principal (Pallodino, 2008).

There seems to be little research on the preparedness of secondary education leaders in the area of special education. While some studies have pointed out that teachers lack proper knowledge and training to serve students that receive special services, few tackle the issue of the leader. With a growing population of students who have special needs it is imperative to find if gaps persist in the training of school leaders.

The first section of this chapter describes the purpose and research questions that guide this study. Next, the specific design for the study including development of the population sample size will be discussed. The third section explains how data will be collected, instrumentation for research, discussion on collection procedures, and how the participants of the study were protected. The fourth section discusses how the qualitative data from the interviews and qualitative survey data were analyzed followed by assumptions and limitations of the study. A summary of the methodology section will conclude the chapter.

Upon analysis of data gathered, recommendations will be offered regarding how higher education programs can meet the needs of aspiring administrators so that all stakeholders in a child's education can benefit. It is the intention of this study involving the preparedness of principals and the perceptions of the 
universities providing the training, a better situation may arise regarding providing the needed services to students with special needs.

\section{Purpose of the Study}

The purpose of this qualitative study is to determine if Missouri high school principals perceive that the training they received from higher education has adequately prepared them for their duties regarding special education. High School principals were interviewed individually and in a focus group, with questions created by the researcher, focusing on their perceptions of principal preparation programs with regards to special education training. Additionally, higher education leaders were surveyed to ascertain if they feel that the programs offered are adequately preparing school leaders in the area of special education. Analysis of data is leading to improvement of leader training programs.

Special education is a diverse field, thus participants only answered questions based upon services to children with learning or behavioral disabilities. Gifted students, students accessing 504 accommodations, and alternatively placed students were not covered in the scope of this study. Data gathered was used to make recommendations to Missouri universities for pre-service principal preparation programs using change theory ideas supported by Kurt Lewin and modern change theorists such as John Kotter. This study also adds to the body of work related to principal preparedness with regards to special education. 


\section{Research Questions}

The following two research questions guide this qualitative study as to bridge a potential gap in secondary school principal's knowledge of special education and what universities provide in their graduate coursework.

1. What is the perception of Missouri secondary school principals regarding special education training received during graduate coursework?

2. What is the perception of university or college of education leaders of special education training for secondary school principals within their institution?

The research questions help focus on the special education areas in which principals feel inadequately prepared to address and which areas higher education leaders feel are covered adequately for today's principal. By gathering this information, recommendations can be made to significantly improve special services for students and provide schools with better equipped leaders.

\section{Design for the Study}

Qualitative procedures were used to gather data for this study. According to Creswell (2009) qualitative procedures for data collection focuses on multiple sources of data collection, natural setting, participants meaning, theoretical lens and interpretive inquiry. Additionally, Hatch (2002) believes that qualitative research is best for collecting perceptions of participants. In qualitative research the researcher plays a very active role in gathering information for the study. With regards to this study, the researcher focused on interviews, a qualitative survey, and reviewing of documents and artifacts to conduct research. Because two distinct 
groups were targeted and a focused stream of data was generated, the sample population would be considered purposive or selective (Creswell, 2009).

Discussing personal experiences, from the view of school principals, provides an avenue to look at issues regarding perceptions of special education training through a constructivist lens. The researcher utilized a constructivist research paradigm, believing that participants have made interpretations of their experiences based on interaction with stakeholders in the environment in which they work (Creswell, 2009). The researcher intentionally engaged in open-ended questions throughout the interview process in order to allow participants opportunity to elaborate on their experiences. Creswell (2009) and Hatch (2002) suggest that using a constructivist paradigm will allow participants to explain their views and form opinions based on their interactions. The participants helped the researcher make sense of the relationship between special education training offered and the perception of special education training needed, which is constructivist in nature (Creswell, 2009). This helped the researcher in making recommendations involving training of future administrators.

The researcher was most interested in the process of which administrators are trained and if that process needs to be changed rather than the outcome of the training. Data was collected through several interviews of Northwest Missouri public high school principals, a focus group of principals and survey data obtained through a short online survey with the deans of education colleges from various Missouri universities. After close analysis of the three data streams, the research 
provided information to the universities of ways to help aspiring principals be more equipped to deal with special education issues that arise.

The researcher also gained access to a variety of documents and artifacts from Missouri universities that outline coursework that an educational leader would expect to take during the preparation program. This includes course listings and curriculum for courses that are offered in conjunction with a graduate degree program.

\section{Population and Sample}

Several principals from Northwest Missouri were asked a range of openended interview questions both individually and through a focus group about their own dealings with special education and the training received while working towards their principal certification. While this is a sample of convenience because of the proximity of the participants, it allows for needed information in a timely manner (Cresswell, 2009). The principals were interviewed at a location of their choosing, which was the building in which they lead. By finding a comfortable interview environment, free from distraction, the researcher was able to maintain a more consistent dialogue with the participant (Cresswell, 2009).

The researcher sent an email to prospective participants outlining the scope of the study with an invitation to join the study via a face-to-face interview (Appendix B). Recipients were given one week to respond before a follow-up phone call was placed. Those who responded favorably were given the opportunity to chose a convenient time and place to be interviewed as well as an informed consent agreement (Appendix C). The researcher explained to the participants that 
pseudonyms would be used to attempt to protect the identity of each participant. Any information that would lead to identification would be changed or omitted by the researcher, with agreement from the participants.

Leaders of education colleges for selected Missouri universities were invited to participate via an email, with a follow-up phone invitation (Appendix D). Those agreeing to participate were emailed the informed consent agreement as well as a link to the online survey (Appendix E). This group of participants was selected based on convenience, as participants were easily accessible and the researcher having an existing relationship with two of the participants (Hatch, 2002). The sample could also be considered "confirming" or "disconfirming", according to Hatch (2002) because they furthered knowledge gained from the interviews of administrators.

The online survey consisted of several open-ended questions to allowed the college leaders to describe their training programs and to give their perspective on how they are adequately training principals with regards to special education.

\section{Data Collection}

\section{Data Collection Procedures}

The focus of this qualitative study was to engage in high school principals to determine their perspectives in training with regards to special education. It was also necessary to gather information from college leaders about their principal training programs. Because two distinct groups were targeted and focused stream of data will be generated, the sample population would be considered purposive or selective (Creswell, 2009). 
The first tier of information was gathered by interviewing several Northwest Missouri high school principals individually and through a focus group. Sound interviewing techniques were used including asking who might give more information, open ended questions and follow-up questions were asked that will help in giving direction to the study (Creswell, 2009).

The second tier of information was gathered through a survey, which was piloted by fellow doctoral students to provide validity. The survey was sent to various leaders or deans of Missouri colleges and universities. Information gathered indicated their perceptions on the effectiveness of their principal training programs in terms of special education. Using change theory ideas, the data collected from principals and college leaders lead to recommendations to Missouri colleges and universities.

\section{Interviews and Focus Group}

Interviews with Northwest Missouri high school principals were semi-structured and conducted in a mutually agreed upon location. Interviews lasted approximately thirty minutes. This type of interviewing allows for a discussion to take place between the researcher and participant (Hatch, 2002). Work from Krueger and Casey (2015) influenced the interview techniques and focus group protocol regarding notice, questions, logistics and moderator responsibilities. Prepared questions were used as a guide in both the interview and focus group (Appendix B and C). Each participant signed the Informed Letter of Consent (Appendix A) and a copy given to each participant's request. All interviews and focus group discussions were audiotaped and transcribed verbatim. Each participant was allowed to read the transcribed interview to make any changes they 
wanted to make. While the participant answered the questions, the researcher listened intently to see if opportunity for follow-up questions existed. At the close of the interview, the researcher asked if there was any other information that could be shared to help in the study (Hatch, 2002).

Because special education is such a diverse field, participants only answered questions based upon services to children with learning or behavioral disabilities. Gifted students, students accessing 504 accommodations, and alternatively placed student issues are not covered in the scope of this study.

\section{Survey}

The second instrument used was a brief cross-sectional survey, which captures the thoughts of deans of college of education for various Missouri universities at one point in time (Creswell, 2009). The survey allowed participants to give their perceptions on how their programs prepared leaders for the principalship of a high school. The advantage of doing a survey for this data collection was a more rapid turnaround time and a transcribed record would be sent via the survey service directly to the researcher.

An expert panel, made of fellow doctoral students and university educators, helped give direction as to what questions were suitable to ask of Missouri university leaders. After examining the questions, several changes were made to narrow the focus of the survey and make it more efficient for the university leaders.

\section{Human Subjects Protection}

The researcher completed IRB certification for protecting participants. In addition, informed consent was obtained from participants through the email that 
was sent to participants, which contained the link to the survey. Within the informed consent letter, the purpose and intent of the study were presented. The researcher was identified as doctoral student and notes that the information collected and data analyzed would be used for dissertation work. Additionally, participants were advised of their rights if they chose to participate in the survey and were provided with contact information for the researchers and course instructors. The survey, which was obtained by participants through surveymonkey.com, was completely confidential. Participants were informed of confidentiality in the sent email. Participants also were made aware that the survey was completely voluntary.

\section{Data Analysis}

\section{Qualitative Data Analysis}

Analysis on the qualitative data was conducted by using the transcripts of the interviews and focus group conducted with the research participants. The researcher reviewed the transcripts and coded the major themes of the interview by using the inductive approach to analysis. The inductive approach means "the data are read searching for particulars that can be put into categories because of their relation to other particulars" (Hatch, 2002; p. 164). The researcher then brought the coded transcripts together to compare them to each other to determine if there were commonalities among the themes or if there were differences. By coding the data individually and determining themes the researcher was able to triangulate the data (Hatch, 2002). The general themes are reported in the findings.

The second research question is addressed through a survey of deans of 
colleges of education in Missouri universities. The researcher used the data as ancillary information to better understand what training is offered in graduate programs at various universities.

\section{Reliability and Validity}

The survey was tested for face validity and content validity by a panel of colleagues. It was piloted to a group of area assistant principals in order to glean issues contained within the survey. Minor changes to the survey were made based on the recommendations of students and instructors.

\section{Limitations, Delimitations and Assumptions}

\section{Limitations}

The most limiting factor in this study is the set of data collected from the perceptions of both principals and college leaders. In order for the data to be used with fidelity, the participants must answer the interview and survey questions honestly.

According to Dillman, Smyth, and Christian (2009) using internet based surveys introduce difficulties with participant response. They argue that because there is little personal attention given to participants, the propensity to delete emails and a minute amount of time investment between researcher and participant it is often difficult to generate response from the given sample (Dillman, Smyth and Christian, 2009). This may have limited the number college leaders to take part in the research. 


\section{Delimitations}

Using a convenience sample for the qualitative portion of the study is less desirable than using other types of sample according to Hatch (2002). The most impactful limitation with regards to the study is that only principals in and around Northwest Missouri were interviewed. While this sample was convenient for the researcher, there may not have been enough data collected to call for large, systematic change in training programs for principals. Another delimitation is the topic of the study itself, which implies that principals needed more instruction on the issues with regards to special education.

\section{Assumptions}

The first assumption being made in this study is that all principals have interactions with special education services. While it is likely that each school has a special education department of some form, it could be that each principal at a school has varying roles concerning special education. As noted previously, the assistant principal position can be somewhat vague in terms of job requirements and special education may or may not be included in their assignments (Kwan, 2009). While it is impossible to know the extent of duties before extending interview requests, the researcher assumed that the leaders have knowledge regarding special education in their building.

The second assumption that is being made with regards to this study is that the dean or supervisors for the college of education at various schools has working knowledge about the curriculum offered in graduate courses and will give honest feedback regarding course offerings. There could be difficulty in gathering data 
regarding their perceptions because they want to communicate a positive message regarding their institution. It took much thought in developing the interview questions so as to build a feeling of trust between the participant and researcher (Hatch, 2002).

In doing qualitative research, the researcher introduced opportunity for personal bias. The researcher feels there was insufficient training with regards to adequately understanding the scope of special education. Multiple decisions dealing with special education have been made in which the researcher felt not fully prepared to make. It was critical that when interviewing the various participants that the researcher maintain neutrality when asking questions and that the upmost respect be given to each university (Hatch, 2002).

\section{Summary}

The research and design methods chapter gave a framework of the case study Northwest Missouri principals concerning the perceptions of the special education training received during their graduate work. The purpose was to inform higher education leaders of gaps that exist in training programs regarding special education. Research questions and the reasoning for the study were established. Next, the population to be interviewed was established and the higher education leaders were selected to be surveyed. The process of data analysis was described and issues of trustworthiness and confidentiality were explained. Limitations, delimitations and assumptions were detailed in this chapter as well. 


\section{CHAPTER FOUR}

\section{RESEARCH FINDINGS}

Educational leaders take on an extremely important role in the education of a child. Expectations of recruiting and mentoring new teachers, supervising an entire staff and student body, ensuring stakeholder communication, managing a sizable budget, school improvement planning, high stakes testing responsibilities, and nightly supervision obligations are just a handful of leader responsibilities that contribute to that education (Lynch, 2012). Factoring in the daily decision-making grind, the role of educational leaders is challenging to say the least. There is one responsibility, because of past and current legislation, that is just as important: The oversight of special education programming and compliance (Lynch, 2012).

The role of the principal has been historically viewed as a middlemanagement position that deals with budgeting, student discipline, rule making, facility decisions and the general management of teachers and students (Brazer \& Bauer, 2013; Wahlstrom, Louis, Leithwood \& Anderson, 2010). The role of principal has largely changed because of the mandates from the No Child Left Behind Act of 2003 and again with the reissuance of Every Student Succeeds Act in 2016 (Roberts \& Guerra, 2017). States, school districts and individual schools are being held more accountable for all student achievement scores, college and career readiness, attendance, etc. which makes it imperative that exemplary leaders are in the role of building administrator (Rammer, 2007). The challenge of finding qualified candidates for administration who are instructionally sound, have the ability to motivate, can engage productively with stakeholders, and have a belief of shared 
leadership is one that hinders the progress of many districts and schools (Vanderhaar, Munoz, \& Rodosky, 2006). Finding quality candidates that have a deep understanding of special education law is almost impossible (McHatton, Boyer, Shaunessy, \& Terry, 2010).

Having the responsibility of LEA (Local Educational Agency) representative for special education purposes is one of the few opportunities in which costly mistakes could lead to severe repercussions to the student, building leader, school and district. Being part of IEP (Individualized education plan) teams, evaluating special education teachers and communicating with parents of students served by special education are all roles that principals or assistant principals could expect to take on. It is extremely important that the training received in becoming a principal provides the proper tools to effectively impact stakeholders in special education.

With over 6 million students nationwide receiving special education accommodations, one third being high school students, it is imperative that high school principals are properly prepared to make critical decisions regarding special education programs (Swanson, 2008). According to the Digest of Education Statistics (2015), developed by the U. S. Department of Education, Missouri has the $20^{\text {th }}$ highest percentage of total public school population being served with IEPs at $14.1 \%$. Based on past trends, it is unlikely that the number of students requiring special services will decrease. This will undoubtedly lead to high school administrators continuing to face challenges with decisions regarding staffing, evaluation of teachers, parental contacts, IEP team decision making and providing the needed leadership to the school for all students to be successful. 
There is a gap between the training of secondary principals and the expectations placed on principals regarding special education (McHatton, Boyer, Shaunessy, \& Terry, 2010). In order for a leader to make sound decisions regarding special education issues, he or she must have staff members in which one could rely on in the process of making decisions, but must also have the schema in which to base his/her opinions. It is of utmost importance for two reasons: a child's education may hinge on those decisions and a poor decision puts the school and the district at risk because of non-compliance to special education law.

This chapter will focus on data collected from seven high school principal interviews, a focus group of four principals from the Northwest Missouri region and a qualitative survey sent to fourteen Missouri university college of education leaders. Other information used to inform this study was course requirements for principal preparation programs that are found online through the graduate studies departments of Missouri universities. Interview and focus group data will be coded, organized into major thematic groupings and analyzed to answer the following research questions:

The following two research questions guide this qualitative study as to bridge a potential gap in secondary school principal's knowledge of special education and what universities provide in their graduate coursework.

1. What is the perception of Missouri secondary school principals regarding special education training received during graduate coursework?

2. What is the perception of university or college of education leaders of special education training for secondary school principals within their institution? 
The research questions help focus on the special education areas in which principals feel inadequately prepared to address and which areas higher education leaders feel are covered adequately for today's principal. By gathering this information, recommendations can be made to significantly improve special services for students and provide schools with better equipped leaders.

Interview setting and participants will be discussed in the first part of this chapter. Subsequently, the findings section will include patterns and themes that were gleaned from the coding process of the interviews and from the focus group. Data from university leaders will also be examined to provide current higher education perceptions. Findings will then be analyzed through the research questions and within the conceptual framework of change theory. This chapter ends with a summary of those findings.

\section{Setting for the Study}

Northwest Missouri has many secondary schools and varies greatly by student population, socioeconomic status and the experience level of the administrators that lead the school. The high schools represented in this study range from over 1500 students to a school with approximately 300 students. This area of Missouri is mostly agricultural, but also includes the more urban area of St. Joseph, where a high percentage of students are served by IEPs as compared to other areas (DESE, 2016). For the purpose of this study only principals that are in schools located in the Northwest region of Missouri were interviewed to find their perceptions on graduate work regarding special education. 
In addition to the interviews and focus group, a group of university leaders were asked to share their perceptions on training that is offered to aspiring school leaders. There are approximately 15 universities in Missouri that provide graduate work for aspiring principals. They have a wide range in total student population, graduate programming and location. Perceptions were gathered from university leaders with student populations of fewer than 3000 students to over 30,000 students. The education school of each university also ranged in faculty size. The largest university had over 20 members and the smallest only 3 .

\section{Relationship of Researcher to Research}

The researcher grew up in Northwest Missouri, having attended elementary and secondary schools in St. Joseph, MO. The researcher obtained a high school teaching certificate in the area of Chemistry through undergraduate work and a Master's Degree in Secondary School Administration. Having taught in St. Joseph and Columbia, Missouri and serving as a Middle and High School Assistant Principal has given the researcher an opportunity to form close relationships with many of the participants of the study.

The researcher has served on many IEP teams and has often felt that there should be more training for administrators with regards to special education. The researcher attempted to stay neutral throughout the interview process, giving no indication of personal thoughts or opinions.

\section{Description of Participants}

The goal of the researcher was to gain perceptions from other Northwest Missouri secondary school principals as to their training regarding special 
education. Participants varied greatly in terms of experience, which gives a unique cross section of data. Experience in being in a principal position ranged from one year to over 20 years in an administrative capacity. Seven principals were interviewed and four participated in a focus group discussion.

The researcher wanted to find out the perceptions that principals held regarding their coursework with regards to special education. Principals were chosen based on their location (Northwest Missouri), which is a sample of convenience because of the proximity of the participants, but allows for needed information in a timely manner (Cresswell, 2009). 7 area principals were interviewed and a focus group of 4 other principals took part in this study. They ranged in experience from 3 years as principal to 15 years of administrator experience.

Survey participants were not asked identifiable questions thus their responses were purely anonymous. The researcher chose the faculty member and/or leader who he felt would have the most knowledge of curriculum covered in the graduate programs for 12 Missouri universities. It seemed from online resources that most of the university leaders had been in their position for at least two years, some much longer than two years upon reading biographical information. One university leader responded that they were not the correct person to provide such insight and directed the researcher to someone with more intimate knowledge of the special education programming for aspiring principals. 


\section{Interview Setting}

Interviews were held at an agreed upon location that would help participants feel as comfortable as possible. The locations were available and convenient to the respondents, and also good for using a recording device to gather interview data (Edwards \& Holland, 2013). The interview and focus group locations were private and provided little disruption to the interview process. Locations included a school office and conference room that provided ample privacy, a classroom that was not being utilized by a classroom teacher and a private conference room at a facility hosting a Missouri Principals conference.

\section{Interviews and Focus Group}

Interview and focus group questions tended to be more open-ended to facilitate a discussion on their perceptions of training received regarding special education and their role regarding special education within the framework of their school and/or district. The principals discussed what they feel are the important roles they take on by serving as principal and were given the opportunity to provide suggestions as to what universities could do to improve coursework for aspiring secondary school leaders. Sound interviewing techniques were used including asking open ended questions and follow-up questions that will help in giving direction to the study (Creswell, 2009). While this is a sample of convenience because of the proximity of the participants, it allows for needed information in a timely manner (Creswell, 2009).

The focus group was used for veteran principals who have more than 10 years experience with high school administration. Focus group respondents were 
recorded in the same way as individual interview participants. The researcher attempted to provide a welcoming atmosphere that would allow participants to feel at ease in answering questions. Small talk, use of humor and providing positive feedback, both verbal and nonverbal were ways that the researcher kept the focus group running smoothly (Krueger \& Casey, 2009).

\section{Data Analysis}

Once the interviews and focus group data was transcribed, the researcher read the findings to find themes, contradictions and confirmations. Prior research, documented in the literature review, was also used in the analysis process. The researcher used a system of coding to determine the important themes that emerged from the transcribed data. The goal of coding, also known as open coding, is to break down data into smaller pieces to help develop meaning (Creswell, 2009). Chunks of data were organized based on words or phrases that were deemed important to the research and could be changed upon reading the transcripts further (Hoepfl, 1997). The categories were then placed under an overlying theme that emerged.

As the researcher coded and organized the data, patterns emerged that would inform the researcher of perceptions that answered the questions posed in the study. Statements were found in the interviews and focus group that could be grouped together because of common themes. Each interview and focus group was handled similarly to ensure reliability of the research. The following categories emerged as the documents were coded:

a. Department Chairperson Position 
b. Process Consultant

c. Social Worker/Counselor Guidance

d. Teacher Supervision

e. Professional Development

f. Role in IEP Meetings

g. Challenging Situations

h. Lack of Adequate Time to Deal with Special Education Issues

i. Lack of Special Education Coursework

j. Little Ongoing Professional Learning Regarding Special Education

k. The Needs of Aspiring Principals

After all categories were extracted from the data, themes emerged and were determined by the axial coding process. Categories were placed into themes based on the relationship of each category, which is consistent with the axial coding process (Strauss \& Corbin, 1990).

The themes that emerged from the twelve categories were: (a) The Organization of Special Education in a Building/District, (b) The Principal's Role in Special Education, and (c) Training of Principals Regarding Special Education. Statements of the participant's perceptions of each theme from the interviews and focus group, as well as other research findings were organized and are documented and detailed in the next section.

\section{Findings from the Data}

Triangulation of the categories, reviewing appropriate literature and viewing through the lens of Kotter's Change Theory produced three distinct themes. Using 
axial coding from the perceptions gathered through interviews of secondary school principals, a focus group of secondary school principals and the survey conducted for perceptions of university leaders produced the following three distinct themes: (a) The Organization of Special Education in a Building/District, (b) The Principal's Role in Special Education, and (c) Training of Principals Regarding Special Education.

\section{Theme 1: The Organization of Special Education in a Building/District}

The first theme that was realized by the data gathered through interviews, the focus group and relevant literature was how schools and/or districts organize the services provided for students with special needs. This includes the structures that are put into place to make sure that the students are getting the services that are needed based on their IEP. Most participants spoke of district level support, specialists that will serve as LEA, process consultants, special services department chairs, special education teachers and regular education teachers.

Participants also brought up the fact that buildings and districts must stay in compliance with the IEP for students. While not specifically speaking to the topic, it seems that they recognize the importance of the reissuance of EASA which requires states to be in compliance in many areas of special education, including learning standards, assessment, IEP goal setting, graduation, accountability and bullying/harassment (Council of Chief State School Officers, 2016).

Sub-Theme: Process Consultant. Several principals spoke of the relevance of having a process consultant for their building that would often help with professional development for the special education teachers and the guidance that 
they give during IEP meetings. The process consultant is a conduit between the Special Services Department at the district level and the Department Chair, teachers and administrators at the building level. Process consultants would often serve as the LEA for the team and answer questions that parents and students would have regarding the testing, data collection and overall delivery of the IEP. Says Principal A, "its nice to have process consultants to help with IEP meetings, they are not here everyday, so when you have an IEP on a day when that person's not here, and of course, somebody has to be there to serve as LEA." Principal L also agrees that the process consultant is an important piece in IEP meetings and that meeting regularly with them helps her understand the needs of the students, teachers and the team in general.

The process consultant would often set up testing for new referrals for a child to receive special services through the special education department. They also oftentimes perform the testing and analyze results as well. Principal D claims, "without the support of the process consultant, the professional development that they provide our teachers, it would stretch our resources even further." This is something that Principal F agrees with as well saying that the process consultant is a part of the IEP team that responds to issues that come up and helps make decisions regarding the IEP. Principal M reiterates this saying, "in the special education process, I work very closely with our process consultant...working hand in hand with the process consultant because she can provide the information (testing data) needed." 
Sub-Theme: Sped Department Chairperson Position. Most principals that were interviewed spoke to the point of having a department chairperson that helped oversee the special education program in their building. In one case, Principal S spoke of not necessarily having a department chair, rather a district representative that would serve in that role especially in IEP meetings. In other cases, the department chair seemed to play a major part in all aspects of special services.

Principal G speaking on the importance of this person especially as the population of students requiring special services on the rise. G states, "I have seen the special education department here grow. It is actually our biggest department right now. The department chair has been an integral part of training new teachers." This speaks to current research which according to the Digest of Education Statistics (2015), developed by the U. S. Department of Education, Missouri has the $20^{\text {th }}$ highest percentage of total public school population in the nation being served with IEPs at $14.1 \%$. Based on past trends, it is unlikely that the number of students requiring special services will decrease.

For several buildings losing the department chair position because of budget cuts was a major issue. In those buildings, the department chair served as the LEA during IEP meetings unless there was a particular reason that the principal needed to attend. Principal F states, "it's going to to increase, probably, some disciplinary or scheduling for those students that are in special education, because this past year we had a department chair that oversaw the special education department and was able to monitor or address some of those issues." Principal C agreed stating, "the 
loss of the department chair in our building is going to impact everyone. Students, special education teachers, regular education teachers and obviously us, administrators." Many are concerned that important pieces are going to be overlooked, which could lead to possible negative consequences.

Principal E brought up and interesting point regarding having someone who works as the department chair. "This person is probably seen more as an administrator because they do not actually teach a course. They are the go to person when we have questions." E talks of how they sometimes serve as an LEA and intervenes on issues before they reach the principal or assistant principal. E says, "they are going to be missed. Or maybe more over-worked because now they are going to be teaching a full class load, but I'm sure that we will be asking them a million questions a week."

Sub-Theme: Social Worker/Counselor Guidance. Most of the participants indicated that counselors and social workers could play a role in helping students that require special services, but they are mostly not involved because the special services department chair usually satisfies that role. Some indicated that the counselors' role would expand because of the loss of the department chairs within some buildings, thus creating a shift in traditional roles.

Principal A stated, “we have five counselors and they don't really counsel like that, but their jobs are more about keeping track of credits and moving you towards graduation, and those kinds of things. So kids that have problems typically end up talking to our social worker more than our counselors." Principal D concluded, "our counselors will have to fill a role within the IEP team because of the loss of the 
department chair position." Still another principal, Principal C stated, "our counselors have not had anything to do with special education, which is a shame because they could be a helpful IEP team member." C talked about more about how the counselors could be of great help, especially as the department chair position was eliminated. "The counselors will definitely have to start helping. They do counsel special education students when they are in crisis, but never made their schedules, etc. They will have a lot of learning to do knowing if kids are graduating through credits or by goals. A lot of classes to learn," C maintains.

\section{Theme 2: The Principal's Role in Special Education}

The second theme that was produced by the data gathered through the interviews, focus group and relevant literature was what role the principal serves regarding the special education process and implementation within the building and/or district. Educational leaders take on an extremely important role in the education of a child. Expectations of recruiting and mentoring new teachers, supervising an entire staff and student body, ensuring stakeholder communication, managing a sizable budget, school improvement planning, high stakes testing responsibilities, and nightly supervision obligations are just a handful of leader responsibilities that contribute to that education (Lynch, 2012). Factoring in the daily decision-making grind, the role of educational leaders is challenging to say the least. There is one responsibility, because of past and current legislation, that is just as important: The oversight of special education programming and compliance (Lynch, 2012). The participants in this research provided more insight into how they lead within the realm of special education. 
Sub-Theme: Teacher Supervision. Principal T put in succinctly in describing how she interacts with special education teachers, "I'm constantly trying to get better at guiding teachers through scheduling. Not classes, but how many minutes? How do you determine, truly, how many minutes a student needs?" Principal A talks about finding ways to support teachers, specifically special education teachers. Principal A states, "mainly just driving by and checking....so checking on them, getting to know their needs because that is a specialty group here in the building, supporting those teachers because you can get burned out pretty quickly in there."

Principal C talks of providing support to those teachers, not just evaluating them through the common evaluation process. Principal C says that teachers need "constant communication from us, as supervisors, so they know that we will support when needed. They also need to know the expectations that we have of them. Getting IEP meetings set up in a timely manner, keeping us compliant as far as their caseloads. Things like that." Part of supervising teachers include working through the evaluation system that is given to them to use. Principal E says, "even though we have to watch for IEP mistakes and things like that, we still have to evaluate them the same as other teachers. Like critical thinking, relationships with students, things like that are looked for when we do a walkthrough."

Principal G spoke of issues finding teachers that are special education certified. "Over the last five years, almost everyone we've hired in the special education department has not even any formal teacher training," G says. G goes on to say that usually a person is just looking to get hired so that they can move into 
another position once it becomes available. G says, "so they are coming in with no special ed background, and also no teaching background, so we have to build them up and train them."

Sub-Theme: Professional Development. Providing professional development to teachers is an expectation of most building leaders. While principals feel comfortable supervising special education teachers for the most part, providing professional development to them with regards to special education specifically, results are much more mixed. While Principal J says, “I'm very comfortable, instructional processes and techniques apply to all students." Principal M states that, "if we are talking about instruction, I'm comfortable with that. When it comes to the needs of the students its not going to matter because special ed or regular ed is going to be all about meeting the needs of the students wherever they are, whatever demographic they're in." Principal $\mathrm{H}$ also states that he is comfortable providing professional development to special education teachers. H states, "I've done a lot of work with the modifications part, more of the co-teaching and class within a class style. I've dealt with a lot and I'd say that I've become a lot more comfortable with that."

Other principals state that instructionally they are able to provide basic professional development in classroom management and parallel curriculum, however IEP paperwork and deciding on specific services are not areas they are comfortable leading. Principal M stated that she is able to lead instructionally, she is not as confident in "the little, the little unique pieces and parts of special ed policy. I'm not comfortable with that and I'm working to learn." Principal C agrees, "I don't 
know that I'm comfortable with the entire process of special services. The testing, the timelines those are things that can really lead to issues for the building and the district." Both principals went on to speak about all of the intricacies involved in the special education process and how that can impact all stakeholders- students, staff, parents and the district.

Sub-Theme: Role in IEP Meetings. IEP meetings are an important part of the special education process. This is where all team members (special education teacher, regular education teacher, parent, LEA, student and others who play a role in the education of the child) come together to help create a meaningful roadmap for the success of the student (Winterman \& Rosa, 2014). Mostly, the principals interviewed served as members on the IEP team when needed or when it was likely to have negative situations arise.

Principal B spoke of sitting in on meetings or being available if needed, "sometimes when there's a meeting, if I know it is one of those situations, I will sit in. Sometimes they will just want to make sure I'm available in case they need me." He also speaks of the importance of special education director and the process consultant being involved. One interesting thing that this principal did not mention is that the team also consists of a regular education teacher and a special education teacher. They are required by law to be there, whereas the principal is not always necessary if another person is serving as the LEA.

On the other side of the spectrum are principals that are very involved with the IEP team, especially when helping running the IEP meeting. Principal J talked about dealing with difficult parents during the IEP meeting is a role that is 
important to take on. Principal M agreed saying, "students that are in the parallel curriculum, I make sure I attend the IEP meetings and make sure those students are getting updated requirements that they need for their IEPs."

While principals had varying roles as a member of the IEP team, they all understood that they could serve as an LEA and help make decisions that could impact students, families and the district. Principal C stated, "sometimes it is tough in meetings because you do not always have the answers right away to questions. If the right parent is there, they will try to catch you in a trap that could cost the district monetarily or in another way that isn't always positive."

Sub-Theme: Lack of Time to Deal with Special Education Issues. Because of the focus on attendance, discipline, parent contact and teacher supervision many principals worried about the increasing role in special education that they may have to be involved in. This worry is realized, especially when factoring in the lack of training that most principals spoke to.

Principal F spoke to how his role is going to change because of how the department chair position is changing. F says, "so the time that I absorb (for special education) that is going to take away time maybe being in a classroom, or dealing with a discipline issue, or meeting with a parent, or contacting on attendance. Attendance is a huge deal right now, and I need all the time I can get to attend to it." $\mathrm{F}$ also talked about the role of the principal and how there just isn't enough time in the day to make sure everything is working smoothly.

Principal A worried about what changes to the special education department was going to look like for assistant principals who may have to shoulder more 
responsibility over special education. A says, “I don't feel comfortable at all, and I don't really know how there's going to be enough time in the day to do what they do already plus spend, run down to the special ed offices and deal with the little things that pop up during the day. A spoke of the amount of training that it would take to get principals to a place of comfort with dealing with special services issues, such as restraining emotionally disturbed students and helping a caseworker write an IEP that was thorough and complete.

Principal E says, “there just isn't enough time in the day to help caseworkers or teachers with writing IEPs. We have evening supervision every other day it seems like, so I can't just go home and look through them." E also talked about the importance of having IEPs written correctly saying, "the paperwork, the documentation is crucial. If we make a mistake and it leads to a student not being as successful as they could be, that ends up on us. And I guess it should, but it really gives parents the upper hand if we are in legal trouble." Principal J agreed, saying "it takes time already dealing with some of the issues that are brought to us. Dealing with a difficult parent, deescalating situations, building relationships. All of that takes time where we could be helping with instruction."

Sub-Theme: Challenging Situations. A survey of principals by Laskey and Karge (2006) found that over 75\% of principals felt ill-prepared to deal with issues surrounding special education, yet more time is devoted daily by leaders to special education than years past (Lynch, 2012). Several principals in this research shared stories of challenging situations that were particularly geared towards special education. From dealing with staff and difficult parents to helping solve issues 
regarding a student's IEP, most had something that brought significant stress that further training may have helped in their decision making process.

Principal D spoke of a time that they ended up having to deal with a complaint made to the Missouri Department of Elementary and Secondary Education. D states, "there was a situation revolving around a parent's thought that we were not implementing an IEP correctly, that the student was not being given accommodations that he deserved. The student was failing a math class, if I remember correctly. Anyway, the parent felt that we were violating the student's rights and took us all the way to DESE. They ended up not winning, but it was a long process just to prove that we were doing what we were supposed to. The student was just being lazy. It was stressful though." These situations happen more often than most think. In fact, according to Murphy (2003) the importance of special education law and instruction needs to be emphasized in order for a principal to be ready for the new challenges that the principalship requires.

Principal M shared a story about a student who was really struggling, and was subsequently tested for qualification for special services. The student did not qualify for services and "having to sit down with parents and explain that and sit down with staff, that's a struggle. But you have to be able to stick to the indicators and standards set forth by the state." Principal G also revealed a story about a student that was graduating, but the parents wanted him to stay until he was 21 because the law says that he can. G says, "I know that he can stay until he's 21, but I don't know all of the legalities on that and so the conversation with parents was difficult because he's a smart kid." 
Other principals explained that difficult situations arise dealing with the least restrictive environment issue. Principal H explains, "a student we had a couple of years ago, we had him placed within a Life Skills classroom and the parent didn't think that was the correct placement for him, and it became a, I guess legal battle or argument over the least restrictive." $\mathrm{H}$ goes to on say that it became an issue that he was not comfortable handling and that eventually the parent brought in legal representation before it was finally resolve. Situations such as this can lead to time away from other duties and cause a lot of emotional stress for principals if they do not have the proper training to deal with special education issues.

Oftentimes, difficult situations arise because of mistakes that are made before a student reaches a particular building. Principal L shared a transportation situation that should have been cleared up the year before coming to high school. L says, "one that comes to mind is when we were servicing students by transporting them to school, and by district policy, they should not have been transporting them. I was called to a meeting to discuss the legalities of them receiving this service. It was my belief that we should keep servicing them instead of them needing to switch schools. It went to the next level to the special services department downtown." L says that even though it was her belief that the transportation should continue, the IEP should have been rewritten a year prior because that service would be taken away. The discussion with the parents were very difficult L maintained.

\section{Theme 3: Training of Principals Regarding Special Education}

The interviews, the focus group, and the graduate coursework that universities require for aspiring principals as shown on university websites 
revealed the third theme, which revolved around the training of principals regarding special education and the lack of continued learning on the subject. According to Murphy (2003), an expert on school leader standards, a typical masters of school administration will include courses such as, "business administration, personnel administration, organizational theory, school finance, supervision of employees, and school facilities" (p. 41). Rarely is special education mentioned in the programming literature. The importance of special education law and instruction needs to be emphasized in order for a principal to be ready for the new challenges that the principalship requires (Murphy, 2003). Because of the legal issues involved with special education, this was the most passionate theme that the participants spoke about.

While special education curriculum may be embedded within some coursework, there are few stand-alone courses offered to prepare aspiring principals for the ever-rising special education population. At Missouri State University, a course named Administration of Special Programs is required for master's level work in educational administration. The course description reads, "designed to provide skills to establish, administer and supervise special education services and other student programs. Programs in the area of special education, guidance, vocational education, early childhood as well as current state and federal programs affecting education are emphasized." (Missouri State University, 2017). While the course looks to provide some special services instruction, it may only be a small piece of the course. 
Sub-Theme: Lack of Special Education Coursework. Several participants spoke to the lack of training with regards to special education. More veteran principals even had trouble remembering what coursework was provided. What they did remember mostly centered around the managerial aspect of school leadership. This would agree with research as Darling-Hammond, Lapointe, Meyerson, Orr, \& Cohen (2007) said, "historically, initial preparation programs for principals in the U.S. have been a collection of courses covering general management principles, school laws, administrative requirements, and procedures, with little emphasis on student learning, effective teaching, professional development, curriculum, and organizational change." It would also reinforce that there is a gap between the training of secondary principals and the expectations placed on principals regarding special education (McHatton, Boyer, Shaunessy, \& Terry, 2010).

Principals B, G and M all agreed that the coursework taken many years ago did not cover special services, except for a school law course. Most programs consisted of courses that focused on the management of a school, not instructional practice and meeting the needs of families that have students in special education. Principal B says, “while I don’t specifically remember any special education classes, we did have school law and that was helpful." Principal G goes on to say, "I would say those classes, the preparation was a lot more on operational type things, management, building, building security. There was maybe a class on one class on curriculum, finance, but it was probably heavily operational." Principal M says that the coursework that was taken, "was almost more philosophical program, where we 
designed the perfect school, social services. There was a finance class within, there were supervision type courses." All three principals thought that while the operational side of the job is important, there are so many things that they have to provide for instructionally and with community engagement that their coursework is almost obsolete now.

Principal E says, "the one class that I can remember was something about exceptional children or something like that. But it was more of a course designed for not just special education, but gifted, etc." Principal training programs reviewed at several institutions had coursework similar to this, as special education was merely placed within a course and only highlighted, not go into depth on.

One principal, Principal J, thought otherwise. J says, "I feel that it did, most of the issues with dealing with parental rights and decision making for the child." The only other principal who felt as though the training received was adequate was Principal A. Principal A, however, was a special education teacher before becoming an administrator and holds a master's degree specifically geared towards special education. A says that while that training has been beneficial for serving as an assistant principal and principal, specific training for administration, "there was not enough. With the issues we have today, principals are also over 504s, and so through that process this last year, I really became more aware of how many students in our building are medicated and have real issues of some sort. My doctoral class gave nothing on special education."

While courses dealing with assessment, instruction and professional development are absolutely needed (Brazer \& Bauer, 2013), there is no mention of 
the responsibilities educational leaders face with specific regards to special education programming and law. Principal D, who had not been an administrator very long says, "it is, how do I put it, disappointing I guess that we haven't been trained on something that is so important. But we learn as we go and hope for the best.” Principal M also touched on this saying, “you know you don't feel like you have to check on the math department for compliance and so... I think that is what is completely different piece about special ed, and that sometimes gets lost in the shuffle because we haven't been trained to make it a priority." Most participants gave the indication that they have learned how to cope with handling special education issues by learning from past experiences.

\section{Sub-Theme: Ongoing Professional Learning Regarding Special}

Education. Principals said that the lack of professional development regarding special education is also contributing to their lack of confidence in dealing with special services issues. Over the past 10 years, there has been a call for principals to gain training at the school district level in may areas (Mitgang, 2012). Principal G spoke of this from a district perspective in terms of programs that are offered and the lack of knowledge of these programs and other ways for special education students to gain needed support. G talks of a situation where parents were asking questions regarding supports, "all of the things that they were saying about voc rehab and CTP, all of those things I don't have a ton of information about. What can he do if I were conducting that meeting by myself as the LEA, I wouldn't have known services outside my wheelhouse, which is our building." Principal A affirmed this saying, "we all go to the law seminars in the fall and all of that type of 
think, but when it comes down to it, there's a lot that we have to check with our downtown, and then a lot of times our director will even have to call the lawyer to find out."

The need for ongoing professional development was something that most of the participants touched on. They also touched on the lack of professional development, in general, that they are given as building administrators. Speaking on behalf of the assistant principals, Principal A states, “they don't know a lot about special education, just what they've learned through experience." This seems to agree with research that claims it has been documented that most administrators are poorly trained with respect to special education instruction (Lynch, 2012). Principal F says, "I don't have the training to deal with a lot of the issues that special ed have to deal with in terms of a lot of the paperwork and the requirements that they have to go through." Principal H agrees saying, "that's what I always feel like I'm walking on eggshells. Am I doing something that's gonna get me in trouble legally?"

Sub-Theme: The Needs of Aspiring Principals. Throughout the country, a call for more urgency is being generated in providing rich training for principals at the university and school district level (Mchatton, Boyer, Shaunessy \& Terry 2010; Mitgang, 2012). Each participant was given the opportunity to speak to what they felt universities should be doing to help aspiring principals both overall and regarding special education.

Principal J says, "more time to mental health and emotional conditions, understanding poverty and underlying conditions are a couple of things I think that 
should be brought to the forefront." J serves at a school with a fairly high rate of poverty, so it would stand to reason that J would feel those are important issues. B stated, "school and community relations. There maybe could be more emphasis on that because that can make or break you as a principal, how well you handle volatile situations or how your school is perceived, whether that's the reality, the perception is the reality." Principal $\mathrm{H}$ says that allowing aspiring principals to have more handon type experiences is important. "You know, it's just, anybody that's been an administrator knows that you can study books, and have discussions, and do all those things, but until you are in the office chair, I guess, you don't know a lot of the stuff you're dealing with and preparing for," H says.

Principal B says that school law is very important. B states, "I don't think we can have too much of that. Part of that's because is changing constantly." Principal G takes this even further speaking about the need for colleges universities to better prepare special education teachers to help take some of the burden off of building and district leaders. "I also feel like colleges and universities really need to start preparing students, or finding students that in interested in special ed, and growing them because there's a huge shortage, and definitely a need."

While most had ideas on what aspiring principals would need coming into as a building leader, many had ideas specifically geared towards special education. Principal $\mathrm{L}$ and $\mathrm{C}$ both spoke of the role of being an LEA during IEP meetings and how they felt unprepared to take on that role. L says, "I think that there could be a lot more input on the role of the LEA. Understanding the role of each position at the table better would help me. I always feel that I'm going to step on someone's toes if 
I interject. It can get confusing." Principal C agreed saying, "the role of LEA is really important. You don't want to make a promise for services and not be able to back that up. You talk about hurting relationships and putting yourself, well the entire team, district in a situation that could be bad." C also spoke about the legal issues that could arise from not being able to follow through on accommodations that are listed in a student's IEP. "If the wrong information is put into an IEP, it could affect teachers trying to accommodate those students. Mistakes could be made and then we all end up involved in a lawsuit."

Principal B, who is a veteran of over 15 years, states, "probably could stand to have a little bit more training about the process that's involved, not just with qualifying students for special ed, but really at the high school level sometimes, the process where students opt out of special ed. I don't believe that I have the training in that. "Principals $\mathrm{H}$ and $\mathrm{E}$ both agree that making special education an top item in terms of training principals. $\mathrm{H}$ says, "I think a graduate program needs to make that one of the top things you are going through as a school administrator." Principal E said, "knowing the process, the initial involvement that you are going to have is important. It's not one of those things you can learn along the way anymore really. You can learn supervision, you can learn, I don't know, how to communicate better. Anymore people want litigation, so this is something really important."

\section{Research Findings}

Looking at the data from interviews and the focus group, there became themes as to what a principal's role is regarding special education, the other people that are important in the process, situations that principals need to be prepared for 
and suggestions presented by participants regarding what could be done to better help prepare aspiring principals as well as current principals. This was based upon their perceptions of their training and the roles that principals take on in the special education process for their building and/or district. The following outline the thoughts of current principals.

\section{Strong Leadership in the Buildings}

Strong leadership is very important to have at any school, regardless the size and student population. Principals have numerous obligations to the stakeholders in a school and/or district. Expectations of recruiting and mentoring new teachers, supervising an entire staff and student body, ensuring stakeholder communication, managing a sizable budget, school improvement planning, high stakes testing responsibilities, and nightly supervision obligations are just a handful of leader responsibilities that contribute to that education (Lynch, 2012). However, because of the ever increasing number of students with disabilities it has been increasingly important to oversee that students are provided with a free and appropriate education, which includes accommodations and the least restrictive environment possible for the success of all students with disabilities (Lynch, 2012).

Part of being a strong leader is being able to address the needs of teachers and students educationally and emotionally. Principal Principal M states that, "if we are talking about instruction, I'm comfortable with that." Principal C says, "constant communication from us, as supervisors, so they know that we will support when needed. They also need to know the expectations that we have of them." While several other participants indicated the same aptitude towards helping teachers and 
regular education students, the problem that was gleaned from this study was that leaders were not near as comfortable leading in the area of special services.

In order to show strong leadership, principals must be able to serve those involved in special education. As for teachers, Principal E says, "even though we have to watch for IEP mistakes and things like that, we still have to evaluate them the same as other teachers. Like critical thinking, relationships with students, things like that are looked for when we do a walkthrough." It is also important that principals are well versed in options that are available to special education students in order to better serve families and students.

\section{Creating More Time to Devote to Special Education}

With all of the responsibilities that a leader has in a building, it is often difficult to carve out time to better serve stakeholders regarding special education issues. Principal F says, "so the time that I absorb (for special education) that is going to take away time maybe being in a classroom, or dealing with a discipline issue, or meeting with a parent, or contacting on attendance." It is important, though, to find balance between student and staff supervision, evaluation, discipline, instructional learning and other areas. The special services department is often the largest in a school, especially in the more urban settings. With up to $20 \%$ of a student population having an IEP, it is imperative that principals look for ways to integrate themselves into special education. Principal M makes the point that, "I think that is what is a completely different piece about special ed, and that sometimes gets lost in the shuffle because we haven't been trained to make it a priority. 


\section{Dealing with Difficult Situations}

Regardless of how integrated a principal is regarding special education, they will undoubtedly come into contact with difficult situations that could possibly put the building and/or district and possibly themselves in a litigious situation. Understanding that dealing with difficult situations are part of the position as principal is paramount. It is assumed that a principal will deal with student behavior in a way that will help the climate of a school. The same could be said for situations that arise regarding special education. Oftentimes, as Principal A stated, "A lot of people are under the impression because your special education, you don't get punished or you don't have consequences. And that's not true." Keeping a focused plan for dealing with difficult situations is key.

Difficult situations can come take on many forms. Student discipline, IEP meetings, conversations with parents and serving in the role as the LEA are just a few that can present interesting and potentially difficult situations. Oftentimes challenging situation can be handled at the building level, by a principal that has the relational capacity and problem solving ability to do so. Sometimes, though, a parent will take things to a level that may be beyond the control of a building principal. Principal Principal D spoke of a time that they ended up having to deal with a complaint made to the Missouri Department of Elementary and Secondary Education. D states, "there was a situation revolving around a parent's thought that we were not implementing an IEP correctly, that the student was not being given accommodations that he deserved." While all challenges can cause stress and 
discomfort, situations such as this can lead principals to wonder how timely training could have prepared them better.

\section{Role of a Principal in the IEP Process}

The role of the principal in the IEP process is very important and they should be trained to be able to participate fully. Principals varied on the part that they play, but all stated the importance of participating with fidelity. Fidelity only can come when one understands the process, particularly during the IEP meeting. Principal M said, "students that are in the parallel curriculum, I make sure I attend the IEP meetings and make sure those students are getting updated requirements that they need for their IEPs." It is this way of thinking that should raise awareness of the need for principals to be properly trained to

\section{Needs for Aspiring Principals}

Principals are expected to be able to speak to instruction, curriculum, assessment, and evaluations, but they are also expected to be able to speak to the legal aspects of the rights of special education students and families (McHatton, et al. 2010). Principal E said, "knowing the process, the initial involvement that you are going to have is important. It's not one of those things you can learn along the way anymore really. You can learn supervision, you can learn, I don't know, how to communicate better. Anymore people want litigation, so this is something really important." The need for more training was an overarching belief from most participants.

Aspiring principals must not only know the IEP process and how to help teachers with professional development, they must know where to turn in case 
things are going badly. Staying on guard for potential situations and being ready to respond is something that must be taught to leaders. Principal H said, "you know, it's just, anybody that's been an administrator knows that you can study books, and have discussions, and do all those things, but until you are in the office chair, I guess, you don't know a lot of the stuff you're dealing with and preparing for." Knowing that principals cannot simply be "learning on the fly" when it comes to something that is as important

\section{Answering the Research Questions}

This section will examine the research questions presented by the researcher and subsequently discusses the impact of the data on the overall guiding question for this research.

\section{What is the perception of Missouri secondary school principals regarding special education training received during graduate coursework?}

The common theme that emerged from the interviews and focus group was that there is not enough training regarding special education through graduate programs that they took part in. While coursework on the basic management of a school was prevalent in participants' answers, there seemed to be little training especially regarding special education. Participants believed that the training they had received did not prepare them to lead professional development, participate in the IEP process, or adequately prepare them for the challenging situations that special education can present.

It was the hope of most participants that universities could provide a better preparation program regarding several issues, but most of all special education. 
They felt that with the litigious atmosphere that surround special education, especially the laws that govern testing, accommodations and serving as LEA it is paramount that universities provide a richer learning opportunity. Though it isn't just the university that bears burden in this area, many stated that local districts have a responsibility to keep leaders "in the know" regarding special education. What is the perception of university or college of education leaders of special education training for secondary school principals within their institution?

While there was not as much data collected from this group as the principals, they mostly conceded that there is not enough coursework within their preparatory programs to adequately prepare principals for special education issues. One participant stated, "constant battles are faced that is not experienced during coursework." They went on to say that there are too many programs that are theoretical in nature and not enough hands on experiences.

One university leader stated upon being asked about potential gaps between coursework and what principals face on a daily basis, "None in our program. We provide some theory, but most of the coursework is practical information that comes from experienced and very successful retired administrators who teach the courses." While it is understandable to be proud of the existing programs, it may be in their best interest to look at coursework through the lens of a practicing principal.

Universities can begin to research what principals face on a daily basis regarding leading the special education aspect of their school. It would not only serve as connection between secondary leaders and university leaders that could lead to overall improvements in graduate programs for aspiring leaders, but a 
connection that could impact a population of students that are too often overlooked. As one principal states of special education, "I think a graduate program needs to make that one of the top things you are going through as a school administrator."

\section{Summary}

Participants in the study offered many insights into the role of the principal with regards to special education and how training has impacted those roles. There is a gap between the training of secondary principals and the expectations placed on principals regarding special education (McHatton, Boyer, Shaunessy, \& Terry, 2010). While research has shown that special education training for leaders is essential to perform their duties with fidelity, little has been done to close the gap between the training aspiring principals and the everyday concerns that they face. Participants gave many instances that contributed to high stress situations or challenges to adequately providing guidance regarding special education issues. The following chapter, Chapter Five, will discuss implications of these findings and give recommendations to help all those involved with helping special education stakeholders. It will also discuss how Kotter's Change Theory could be used to entice changes to programs for aspiring principals. 


\section{CHAPTER FIVE}

\section{DISCUSSION AND IMPLICATIONS}

Educational leaders take on an extremely important role in the education of a child. Expectations of recruiting and mentoring new teachers, supervising an entire staff and student body, ensuring stakeholder communication, managing a sizable budget, school improvement planning, high stakes testing responsibilities, and nightly supervision obligations are just a handful of leader responsibilities that contribute to that education (Lynch, 2012). Factoring in the daily decision-making grind, the role of educational leaders is challenging to say the least. There is one responsibility, because of past and current legislation, that is just as important: The oversight of special education programming and compliance (Lynch, 2012).

Each participant in this study had a concern, to some degree, that they were ill-prepared to take on the oversight of special education programming at their respective school. Though first-hand experience has often been the way for professional growth in this area, most were concerned that there was opportunity for either negative consequences for missteps taken or a lack of serving this large population in beneficial ways.

Most participants could not remember their coursework well enough to know what would need to be changed in order to give aspiring leaders the needed professional development to provide oversight of special education programming and compliance. This lack of data makes it difficult to provide guidance in changing coursework in the coming years to meet the given need, especially as school laws 
change, lawsuits are filed and schools are increasingly being held to higher standards for all students.

As a high school administrator who handles special services programming and compliance issues, this researcher has a genuine interest in preparing future leaders to be capable and confident to serve this growing sect of our student population.

\section{Discussion of Findings}

The data from the interviews and focus group was analyzed through Kotter's 8-step Process for Leading Change. From the research findings, three main themes and 11 sub-themes were found using the axial coding technique. The first them were the Organization of Special Education Services in a Building/District, which was broken into 3 sub-themes: (a) The Department Chairperson, (b) the Process Consultant and (c) Social Worker/Guidance Counselor. The second theme was The Principal's Role in Special Education, which was broken down into 4 sub-themes: (d) Teacher Supervision, (e) Professional Development Provided, (f) Role in IEP Meetings and (g) Challenging Situations. The third theme was Training of Principals Regarding Special Education, which was broken down into the following subthemes: (h) Lack of Special Education Coursework, (i) Little Ongoing Professional Learning Regarding Special Education, (j) Lack of Adequate Time to Deal with Special Education Issues and (k) The Needs for Aspiring Principals. 


\section{Kotter's Change Theory}

Kotter (1996) believes that in order for an organization to be successful, systematic change using his renowned 8-step Process for Leading Change is best. The 8 steps include:

"Establishing a sense of urgency, creating the guiding coalition, developing a vision and strategy, communicating change vision, empowering employees for broad-based action, generating short-term wins, consolidating gains and producing more change, and anchoring new approaches in the culture." (Kotter, 1996)

Kotter's method has been widely regarded as an instrument that can be of use for a wide variety of organizations (Pollack \& Pollack, 2015). His process includes looking at differences between management and leadership, factoring in organizational weaknesses, and cultural obstacles to change (Kotter, 2006). It stands to reason that many universities suffer from similar obstacles as other organizations, thus using Kotter's work as a framework to funnel data found from this study will lead to higher education change with regards to principal preparation programs.

One university leader said that in terms of exacting change in current curriculum the steps are commonly, "the director submits the request to the Dean, the dean sends it to the Education Division. It then moves to Graduate Affairs who either approve it or send it back for more information. $99 \%$ of the time it is approved." From this account, it seems that once a change is introduced, the leadership of the university must show the importance of the change and how it 
could impact future students. According to Kotter (2011), setting a direction is the first important aspect of leadership. Given that the primary goal of leadership is dealing with change, "setting the direction of that change is fundamental to leadership" (Kotter, 2011, p. 41).

Kotter claims that there is a distinct difference between creating a vision and planning. "Creating a vision is the art of utilizing data and direction-setting to identify the purpose of the organization. These statements need not be innovative or creative; they simply need to identify the desired outcome for the organization" (Kotter, 2011. p.41). Long-range planning involved analyzing and dissecting the steps that an organization or company will take to reach decided upon vision. Longrange planning oftentimes fails (especially without a vision) because if one step in the plan fails, the entire long-range plan fails.

This study, from the perceptions of the participants, shows that there is an urgency in developing a better way of preparing aspiring leaders in the area of special education. That urgency could spur movement, as one university leader said, "A major gap is actually manipulating and being in the true position of a principal. On a daily basis, you are needing to meet the needs of not only students, but also other staff and teachers. There are battles that are faced that is not experienced during coursework required for the Administration Degree." This leader also states, "I believe that there is not enough coursework and particular graduate design that assists prospective principals in better preparing special education interactions." 


\section{Impact of the Principal on Special Education Delivery}

One university leader proclaimed, "with being a principal, you are forced to accommodate and be flexible in various atmospheres and learning environment." All participants agreed with this statement in explaining the roles they take on with regards to special education. While participants described various roles, some more involved than others, all acknowledged that regardless of the role they play it is important for them to be knowledgeable or know who to go to when needed. Though one participant, Principal C, summed it up nicely saying, "at the end of the day, decisions made by others is still a reflection of my own leadership and land us in court."

Principals play an important role when it comes to IEP meetings. Oftentimes, IEP meetings can seem confrontational and/or more of a discipline meeting instead of looking at what services are needed to make sure the educational gap is reduced for a student (Fialka \& Fialka-Feldman, 2017; Dillberto \& Brewer, 2014). Disagreements with parents will happen and conflicts will emerge between team members (Jones \& Passey, 2004; Feinberg, Moses, Engiles, Whitehorn \& Peter, 2014). The principal's role varies in an IEP meeting according to the participants in this study. More often than not the principal will be serving as the LEA, in the meeting because of tense relationships with the parents, or as a confidence booster to a hesitant team member. Regardless of the role, it is imperative that principals have the tools necessary to understand what needs to happen at an IEP meeting and what the school and/or district is legally bound to regarding the IEP. 
Supervision of special education teachers is a task that is different than supervising regular education teachers. Special education teachers should be held to the same standard of using instructional best practices and forming positive student relationships, but they are also charged with making sure that IEPs are being written correctly and are being followed by regular education teachers. The writing process of the IEP is key to develop a plan that will help students progress towards successful completion of their formative education (Dillberto \& Brewer, 2014). As Principal G stated, "there is a mountain of paperwork with special education." It is the principal's job, in many circumstances, to understand the paperwork associated with IEPs, evaluations, educational data collected on students and the timeframe in which those items are to be completed.

Principals are expected to be able to speak to instruction, curriculum, assessment, and evaluations, but are also expected to be able to speak to the legal aspects of the rights of special education students and families (McHatton, et al. 2010). Principals must be continually working with all stakeholders to ensure compliance of the special education department. Parents, students, special education teachers, regular education teachers and other stakeholders all need to be communicated with in order for all to be on the same page regarding special services. The student receiving services has been deemed to be deficient in their ability to learn and deserve to have a team that advocates for their educational gap to be lessened. 


\section{University Graduate Programs for Principals Regarding Special Education}

It is quite clear from the participants' viewpoint, that it is imperative that graduate programs prepare aspiring principals in a different way. From interview data, 10 out of 11 interview participants stated that they didn't receive what they consider ample training for dealing with special education. While several had stated that it had been many years since they have participated in a principal preparatory program, they lamented that they had to use on the job experience to learn enough about the special education process in order to serve in their position. This serves in contrast to what one university leader stated about their preparatory program saying their mission is, "preparing knowledgeable and skilled K-12 leaders who serve all students and staff in an exemplary manner." In order to serve all students and staff, it is imperative that special education is a part of the curriculum.

The importance of special education law needs to be emphasized in order for a principal to be ready for the new challenges that the principalship requires (Murphy, 2003). Finding those quality candidates that have a deep understanding of special education law is almost impossible (McHatton, Boyer, Shaunessy, \& Terry, 2010). Universities must stay current on special education law and pass that along to aspiring principals. Principals spend every day dealing with situations that could cause serious legal ramifications for the school, the district and personally. School Law, which is a course that many universities offer during the graduate course of study for an aspiring leader. However, that is a very broad area that includes other aspects of supervising such as teacher evaluation, budgeting, and handling 
discriminatory issues. A course just regarding special education law would be helpful to aspiring leaders to have a more focused experience.

Participants are well aware that there are other courses that must be taught in order for a person to take on the role of principal, including instructional best practices, supervision and community relations. Principal F stated, "I hate to see more requirements put on, and more hours put on to somebody that's wanting to get into this field." However, F goes on to say that in order for a principal to be comfortable with and to adequately lead special education changes in training is a must. Principal G stated regarding universities needing to offer a special education training course to aspiring principals, "this is an area, we have a great need, and so I definitely feel there needs to be a dedicated class for administrators." All but one principal indicated a level of uneasiness with regards to handling situations regarding special education. This uneasiness, or as Kotter (1996) would say is urgency, could fuel change from universities to make the needed changes to existing programs.

\section{Limitations to the Study}

The most limiting factor in this study is the set of data collected from the perceptions of both principals and college leaders. In order for the data to be used with fidelity, the participants must answer the interview and survey questions honestly. Another issues that arose is that the researcher's relationships with the participants may have led participants to not fully represent their dissatisfaction with their current knowledge of special services.

According to Dillman, Smyth, and Christian (2009) using internet based 
surveys introduce difficulties with participant response. They argue that because there is little personal attention given to participants, the propensity to delete emails and a minute amount of time investment between researcher and participant it is often difficult to generate response from the given sample (Dillman, Smyth \& Christian, 2009). This may have limited the number college leaders, only three, to take part in the research.

\section{Implications for Practice}

From the research conducted and data analyzed, along with literature reviewed, the researcher has found the following perceptions regarding special education training during participants' coursework and the role that the principal plays in the special education process. Furthermore, recommendations are made to better prepare aspiring principals in leading special education in their building and/or district. Given that the primary goal of leadership is dealing with change, "setting the direction of that change is fundamental to leadership" (Kotter, 2011, p. 41).

1. Principals must be knowledgeable about and willing to engage in the IEP process. Little training lent itself to the IEP process, so it is paramount that principals seek out experts within their building and/or district (special education teachers, department chairs, process consultants, etc. Universities should provide a framework for how IEP meetings should be ran, including the roles of the stakeholders. Even if a principal is not serving as an LEA, there is a level of responsibility that the principal takes on to ensure accommodations are being given to the student. 
2. Difficult situations present themselves in many ways. From discipline of special services students to handling claims from parents that their child is not receiving the services in an IEP, all situations must be dealt with in a manner that will help the student while keeping the school compliant with special education law. Universities could include in a special education course, a series of simulations that students could practice dealing with. While that type of activity is not always at the pace of real situations that occur, the background and thought process used would be of assistance.

3. Universities must give attention to the process of how a student is referred to and tested for special services. There are very strict guidelines on how a student qualifies and it is based on testing results and observation data. There is also a strict timetable in which steps need to be completed. It would be good for a principal to have working knowledge of that systematic approach.

4. Universities need to include coursework specifically regarding special education supervision. While supervising instructionally the special education teacher is similar to regular education, there are other nuances that must not be overlooked. Those that are case managers for special education students need to held accountable to staying within timeframes set forth by special education law.

5. Coursework should include information on what services are there for students as the transfer from high school to the workforce or further 
education. Several principals spoke about not being able to adequately counsel families in student options. Whether it is partner agencies or how IEPs can be utilized in higher education settings, principals should have a working knowledge to at least provide some assistance to parents.

6. It is also of note that districts need to provide ongoing professional development must be given to principals and in a timely manner regarding special education. It is likely not enough there was not enough training within their graduate programs prepare for special education issues. School law changes, and with regards to special education, ongoing professional development needs to meet the needs of leaders.

7. The Missouri Department of Elementary and Secondary Education should play a role in how principals are training with regards to special education. New standards for Missouri principals were put in place in 2015, which trumped the previous ISLLC standards (Interstate School Leaders Licensure Consortium Standards). The new state standards say that principals should "strive for the equity of educational opportunity and culturally responsive practices to promote each student's academic success" (DESE, 2015 p. 11). Working with a Regional Professional Development Center, such as the Northwest Regional Professional Development Center in this case, should be paramount to help assess the needs of aspiring principals with regards to special education training. This could be accomplished through the Missouri Leadership Development System and the two-year Emerging Leader coursework. 
The researcher understands the difficulty in adding in more coursework to an existing program. The special education population is growing and it would be wise to incorporate learning objectives geared towards the technical aspects of special education into state training programs.

\section{Implications for Future Research}

The body of research currently about how the leadership style of a principal impacts a building is quite large, however there isn't as much regarding their role within special education. Future research could be expanded to speak to more principals outside of Northwest Missouri to get a broader spectrum of perspectives to add to this particular body of research. It would also be interesting to look at other changes that have been made to principal training to see how those changes have occurred. Have they been because of perceived principal needs, or have they come because of legislative influence?

Another piece of research that one might find interesting is that of how rural principals feel about their role within special education and if they feel prepared. Oftentimes, rural principals face different challenges than those working in a more urban or suburban area. Rural principals usually do not have the advantage of multiple layers of support, especially when it comes to special education.

Research that takes into account parent and student perceptions on their own experience with special education may be interesting research. Finding gaps between what is expected by parents and what is given by a school or district and what principals and/or teachers feel as though they provide might be beneficial to help students find success. 
Using John Kotter's 8-Step Change Model gives a beginning stage framework to enact change at the university level with regards to special education training for aspiring principals. Creating a sense of urgency for policymakers to change is only the first step towards transformational change. Further study could be done to see if the next seven steps are applicable to seeing changes to graduate coursework.

\section{Conclusion}

According to the Missouri Professional Standards for Educational Leaders Standards principals, "create and sustain a school environment in which each student is known, accepted and valued, trusted and respected, cared for and encouraged" (DESE, 2015 p. 13.).

Principals are charged with handling budgets, promoting community engagement, providing avenues for improved instruction, and many other important tasks. One such task, leading the special education department in their building, is of major concern. Listening to Northwest Missouri principals and their perspective on the role they play in special education and the training that they received regarding special education there seems to be a very large gap. It is paramount that every student be given the chance to succeed educationally, which is something that special education can provide. Principals need to to be able to help provide guidance in this area to not only help students succeed, but to protect teachers, the school, the district and themselves from a legal perspective. Because of this need, it is essential that universities feel the urgency and listen to the principals' perceptions regarding gaps in their training. This would be of extreme benefit to many aspiring high school leaders. 


\section{References}

Andrews, R. \& Gogan, M. (2002). Defining preparation and professional development for the future. Educational Administration Quarterly, 38(2), 233-256.

Angelle, P. \& Bilton, L. Confronting the unknown: Principal preparation training in issues regarding special education. AASA Journal of Scholarship and Practice $5(4), 5-9$.

Baldwin, T. T. \& Ford, J. K. (1988). Transfer of training: A review and directions for future research. Personnel Psychology, 41(1), 63-105.

Boser, U. (2009). Special education: A full report. Retrieved from http://www.centerforpubliceducation.org/Main-Menu/Evaluatingperformance/Special-education-At-a-glance/Special-education-A-betterperspective-full-report.html

Brazer, S. D \& Bauer, S. C. (2013). Preparing instructional leaders: A model. Educational Administration Quarterly, 49(4).

Burnes, B. (2004), Kurt Lewin and the Planned Approach to Change: A Re-appraisal. Journal of Management Studies, 41: 977-1002. doi: 10.1111/j.14676486.2004.00463.x

Colarusso, R.P \& O’Rourke, C.M. (2006). Special education for all teachers. Dubuque, Iowa: Kendall/Hunt.

Collins, R. (1979). The credential society. An historical sociology of education and 
stratification. New York: Academic Press.

Cooner, D., Tochterman, S., \& Garrison-Wade, D. (2005). Preparing principals for leadership in special education: Applying ISLLC standards. Connections: Journal of Principal Preparation and Development, 6, 19-24.

Cooper, B. \& Boyd, W. (1987). The evolution of training for school administrators. In J. Murphy \& P. Hallinger, Approaches to administrative training and education (pp. 3-27). Albany, NY: SUNY Pres.

Creswell, J.W. (2009). Research design: Qualitative, quantitative, and mixed methods approaches. Los Angeles: SAGE.

Cross, F. (2016). Teacher shortage areas nationwide listing 1990-1991 through 2016-2017

Darling-Hammond, L., LaPointe, M., Meyerson, D., Orr. M. T., \& Cohen, C. (2007). Preparing school leaders for a changing world: Lessons from exemplary leadership development programs. Stanford, CA: Stanford University, Stanford Educational Leadership Institute.

Dillberto, J. A. \& Brewer, D. (2014). Six tips for successful IEP meetings. Teaching exceptional children 47(2). 128-135.

Dillman, D. A., Smyth, J. D., \& Christian, L. M. (2009). Internet, mail, and mixed-mode surveys: The tailored design approach. Hoboken, New Jersey: Wiley \& Sons.

Digest of Educational Statistics (2016). U.S. Department of Education.

Dornbusch, S. M., \& Glasgow, K. L. (1996). The social structures of schooling. Annual Review Of Psychology, 47(1), 401.

Edwards, R. \& Holland, J. (2013). What is qualitative interviewing. London: 
Bloomsbury Academic.

Feinberg, E., Moses, P., Engiles, A., Whitehorn, A., Peter, M. \& Center for Appropriate Dispute Resolution in Special Education. (2014). In the best interest of the child: IEP meetings when parents are in conflict.

Fink, A. (2009). How to conduct surveys: A step-by-step guide. Los Angeles, CA: Sage. Ford, J. K. \& Weissbein, D. A. (1997). Transfer of training: An updated review and analysis. Performance Improvement Quarterly, 10(2), 22-41.

Hatch, J. A. (2002). Doing qualitative research in education settings. Albany, NY: State University of New York Press.

Heppner, P. P. \& Heppner, M. J. (2004). Writing and publishing your thesis, dissertation, and research. Belmont, CA: Brooks/Cole.

Hoepfl, M. (1997). Chosing qualitative research: A primer for technology education researchers. Journal of Technology Education, 9(1), 47-63.

Kezar, A. (2014). How colleges change: Understanding, leading, and enacting change. New York: Routledge.

Kluger, R. (2011). Simple justice: The history of Brown v. Board of Education and Black America's struggle for equality. New York: Vintage.

Kotter, J. P. (1996). Leading change. Boston, MA:Harvard Business Press

Kotter, J. P. (2011). What leaders really do. In Harvard business review's 10 must reads on leadership (pp. 37-55). Boston, MA: Harvard Business Review Press. Reprinted from Harvard Business Review, 1990).

Krueger, R. A. \& Casey, M. A. (2009). Focus groups: A practical guide for applied research ( $4^{\text {th }}$ ed.). Thousand Oaks, CA: Sage Publications. 
Kwan, P. (2009). The vice-principal experience as a preparation for the principalship. Journal of Educational Administration, 47(2), 191-205.

Lashey, C. (2007). Principal leadership for special education: An ethical framework. Exceptionality, 15(3), 177-187.

Lewin, K. (1951). Resolving Social Conflicts and Field Theory in Social Sciences. Washington, DC: American Psychological Association.

Lynch, J. M. (2012). Responsibilities of today's principal: Implications for principal preparation programs and principal certification policies. Rural Special Education Quarterly, 31(2), 40-47.

McHatton, P. A., Boyer, N., Shaunessy, E., \& Terry, P. M. (2010). Principals' perceptions of preparation and practice in gifted and special education content: Are we doing enough? Journal of Research on Leadership Education, 5(1). 1-22.

Missouri Department of Elementary and Secondary Education (2018). Regional professional development centers. Retrieved from https://dese.mo.gov/educator-quality/educator-development/leadershipacademy

Missouri Department of Elementary and Secondary Education (2015). Professional standards for educational leaders. Retrieved from https://dese.mo.gov/sites/default/files/Prof-Standards-Educ-Leaders.pdf Missouri Department of Elementary and Secondary Education (2016). Becoming certified as an administrator. Retrieved from: https://dese.mo.gov/educatorquality/certification/become-certified-administrator. 
Missouri State University. (2017). Graduate catalog. Retrieved from https://graduate.missouristate.edu/catalog/prog_Educational_Administratio n.htm

Mitgang, L. (2012). The making of the principal: Five lessons in leadership training. Retrieved from http://www.wallacefoundation.org/knowledgecenter/school-leadership/effective-principal-leadership/Documents/TheMaking-of-the-Principal-Five-Lessons-in-Leadership-Training.pdf Murphy, J. (2003). Reculturing educational leadership: The ISSLC standards ten year out. Retrieved from the National Policy Board for Educational Administration website: https://www.npbea.org/Resources/ISLLC_10_years_9-03.pdf

National Policy Board for Educational Administration (2015). Professional Standards for Educational Leaders 2015. Reston, VA: Author.

Palladino, J. M. (2008). Preparing school principals for special education administration: A new model of leadership decision-making. John Ben Shepperd Journal of Practical Leadership.

Peterson, K. (2002). The professional development of principals: Innovations and opportunities. Educational Administration Quarterly, 38(2), 213-232.

Pollack, J. \& Pollack, R. (2014). Using kotter's eight stage process to manage an organizational change program: Presentation and practice. Systematic Practice and Action Research, 28(1), 51-66.

Rammer, R. A. (2007). Call to action for superintendents: Change the way you hire principals. Journal of Educational Research, 101(2), 67-76. 
Ravitch, D. (2000). Left back: A century of failed school reforms. New York: Simon \& Schuster.

Roberts, M. B. \& Guerra, F. R. (2017). Principal perceptions of their knowledge in special education. Current Issues in Education, 20(1), 1-16.

Rooke, D. \& Torbert, W. R. (2011). Seven transformations of leadership. In Harvard business review's 10 must reads on leadership (pp. 137-161). Boston, MA: Harvard Business Review Press. (Reprinted from Harvard Business Review, 2005).

Rousmaniere, K. (2007). Presidential address to the principal's office: Toward a social history of the school principal in North America. History of Education Quarterly, 47(1), 1-20.

Singer, J. \& Butler, J. (1987). The education for all handicapped children act: Schools as agents of social reform. Harvard Educational Review, 57(2), 125-153.

Snyder, T. D., de Brey, C., \& Dillow, S. A. (2017). Digest of Education Statistics 2016, National Center for Education Statistics.

Strauss, A. \& Corbin, J. (1990). Basics of qualitative research: Grounded theory procedures and techniques. Newbury Park, CA: SAGE Publications Incorportated.

Swanson, C. B. (2008). Special education in America: The state of students with disabilities in the nation's high schools. Bethesda, MD: Editorial Projects in Education.

Taylor, S. J., Bogdan, R., \& DeVault, M. (2016). Introduction to qualitative research methods: A guidebook and resource. Hoboken, New Jersey: Wiley \& Sons. 
Tyrack, D. \& Hansot, E. (1982). Managers of viture: Public school leadership. United States: Simple Books.

U.S. Department of Education (1995). The improving america's schools act of 1994. Retrieved from https://www2.ed.gov/offices/OESE/archives/legislation/ESEA/brochure/ia sa-bro.html

U.S. Department of Education (2010). Law and guidance: No child left behind. Retrieved from https://www2.ed.gov/policy/elsec/leg/esea02/index.html

U.S. Department of Education, National Center for Education Statistics (2012). Digest of Education Statistics, 2011.

U.S. Department of Education, Office of Postsecondary Education (2016). Teacher shortage areas nationwide listing 1990-1991 through 2016-2017. Retrieved from https://www2.ed.gov/about/offices/list/ope/pol/tsa.doc.

Vanderhaar, J. E., Muñoz, M.,A., \& Rodosky, R. J. (2006). Leadership as accountability for learning: The effects of school poverty, teacher experience, previous achievement, and principal preparation programs on student achievement. Journal of Personnel Evaluation in Education, 19(1-2), 17-33. doi:http://dx.doi.org/10.1007/s11092-007-9033-8

Wahlstrom, K. L., Louis, K. S., Leithwood, K., \& Anderson, S. (2010). Investigating the links to improved student learning. University of Minnesota.

Walters, D. (2004). The relationship between postsecondary education and skill: Comparing credentialism with human capital theory. The Canadian Journal of Higher Education, 34(2), 97-124. 
Winterman, K. G. \& Rosas, C. E. (2014). The IEP checklist: Your guide to create a meaningful and compliant IEP. Paul H. Brooks Publishing. Baltimore, MD. Wood, A. L. (2005). The importance of principals: Site administrators' roles in novice teacher induction. American Secondary Education, 33(2), 39-62 


\section{Appendix A}

\section{Informed Letter of Consent}

The Department of Educational Leadership and Policy Analysis at the University of Missouri supports the practice of protection for human subjects participating in research. The following information is provided for you to decide whether you wish to participate in the present study. You may refuse to sign this form and not participate in this study. You should be aware that even if you agree to participate, you are free to withdraw at any time. If you do withdraw from this study, it will not affect your relationship with this unit, the services it may provide to you, or the University of Missouri.

\section{Purpose of the Study}

The purpose of this qualitative study is to determine if Missouri high school principals perceive that the training they received from higher education has adequately prepared them for their duties regarding special education. High School principals were interviewed, with questions created by the researcher, focusing on their perceptions of principal preparation programs with regards to special education training. Additionally, higher education leaders were surveyed to ascertain if they feel that the programs offered are adequately preparing school leaders in the area of special education. Analysis of data is leading to improvement of principal training programs.

\section{Procedures}

By giving your written consent to participate in the study, you are consenting to (a) be interviewed or be a member of a focus group for a maximum of one hour, and/or (b) provide relevant documents, and/or (c) be available for follow up questions for a maximum of one hour. With your permission at the time of your interview(s) or focus group, the conversation will be audio recorded, and the recording will be kept in a secure location for seven years after it is transcribed. If you do not give permission for such recording, it will not be done. All materials related to the study will be stored in a locked file cabinet within a locked office when not in use. You may choose to receive a copy of the finished study.

\section{Risks}

There are no risks to you associated with participating in this study.

\section{Benefits}

The benefits of principals participating in this study include helping principal training programs become more aligned with the needs of leaders regarding special education and contributing to the overall body of research in this area. The benefit to university leaders include having a reflective view of programs offered to aspiring 
principals as well as reflection on how the programs develop principals that are well versed in special education issues.

\section{Participant Confidentiality}

Names of individuals and agencies will be collected, they will not be used in any written reports of the findings of the study. Through use of a data coding system and pseudonyms, diligent effort will be made to preserve the anonymity of participants and agencies.

Permission granted on this date to use and disclose your information remains in effect indefinitely. By signing this form, you give permission for the use and disclosure of your information for purposes of this study at any time in the future.

\section{Refusal to Sign Consent and Authorization}

You are not required to sign this Consent and Authorization form and you may refuse to do so without affecting your right to any services you are receiving or may receive from the University of Missouri or to participate in any programs or events of the University of Missouri. However, if you refuse to sign, you cannot participate in this study.

\section{Cancelling This Consent and Authorization}

You may withdraw your consent to participate in this study at any time. You also have the right to cancel your permission to use and disclose further information collected about you, in writing, at any time, by sending your written request to: Luke McCoy, 5303 Stoneridge Drive, St. Joseph, MO 64507.

If you cancel permission to use your information, the researchers will stop collecting additional information about you. However, the research team may use and disclose information that was gathered before they received your cancellation, as described above.

\section{Questions About Participation}

Questions about procedures should be directed to the researcher(s) listed at the end of this consent form.

\section{Participant Certification:}

I have read this Consent and Authorization form. I have had the opportunity to ask, and I have received answers to, any questions I had regarding the study. I understand that if I have any additional questions about my rights as a research participant, I may contact the University of Missouri's Campus Institutional Review Board at umcresearchcirb@missouri.edu, call 573.882.9585, or write the Campus Institutional Review Board, Office of Research, University of Missouri, 483 McReynolds Hall, Columbia, MO 65211. 
I agree to take part in this study as a research participant. By my signature I affirm that I am at least 18 years old and that I have received a copy of this Consent and Authorization form.

Type/Print Participant's Name

Date

Type/Print Researcher's Name

Date

\section{Researcher Contact Information:}

Luke McCoy

Carole Edmonds, Ed.D.

Researcher

Faculty Advisor

5303 Stoneridge Drive

Educational Leadership \&Policy Studies

St. Joseph, MO 64507

Northwest Missouri State University

816.261 .0812

Maryville, MO

luke.mccoy@sjsd.k12.mo.us

660.562 .1258

cake@nwmissouri.edu 


\section{Appendix B}

\section{Interview questions}

Pseudonym:

1. Would you please tell me a bit about your professional background? How long have you been a principal in the high school setting?

2. What do you feel are some of the important roles you serve in as a principal?

3. What graduate programs have you participated in and at what college/university?

4. How is special education structured in your building?

5. What role do you play in special education at your school?

6. Can you think of a time where a difficult situation arose from a special education issue at your school or district and what was your role in handling the situation?

7. Thinking back to the graduate coursework, can you specifically speak to training regarding special education issues?

8. How do you feel that coursework prepared you to handle questions regarding legal situations that arise from special education issues? Please give examples if you can.

9. How comfortable are you leading special education professional development and the instructional needs of your teachers regarding special education students?

10. In general, what changes could be made to principal preparation programs that universities could address? 
11. Are there changes that could be made specifically regarding special education to principal preparation programs? If so, would you please share those proposed changes?

Thank you very much for your time today. You have shared a great deal of information, which will be very helpful in my research regarding Principals' perception of special education training received. Is there anything else that you would like to add regarding this topic?

Upon finishing the interview process, transcripts of all interviews will be obtained. I'll share your transcript with you and if you feel as though I've not represented your thoughts accurately please let me know via email or phone call. Again, thank you very much for your time and insight. 


\section{Appendix C}

\section{Focus Group Questions}

1. Would you please tell me a bit about your professional background? How long have you been a principal in the high school setting?

2. What do you feel are some of the important roles you serve in as a principal?

3. What graduate programs have you participated in and at what college/university?

4. How is special education structured in your building?

5. What role do you play in special education at your school?

6. Can you think of a time where a difficult situation arose from a special education issue at your school or district and what was your role in handling the situation?

7. Thinking back to the graduate coursework, can you specifically speak to training regarding special education issues?

8. How do you feel that coursework prepared you to handle questions regarding legal situations that arise from special education issues? Please give examples if you can.

9. How comfortable are you leading special education professional development and the instructional needs of your teachers regarding special education students?

10. In general, what changes could be made to principal preparation programs that universities could address? 
11. Are there changes that could be made specifically regarding special education to principal preparation programs? If so, would you please share those proposed changes?

Thank you very much for your time today. You have shared a great deal of information, which will be very helpful in my research regarding Principals' perception of special education training received. Is there anything else that you would like to add regarding this topic?

Upon finishing the interview process, transcripts of all interviews will be obtained. I'll share your transcript with you and if you feel as though I've not represented your thoughts accurately please let me know via email or phone call. Again, thank you very much for your time and insight. 


\section{Appendix D}

\section{University Leader Survey}

1. What is your mission in training prospective high school principals?

2. How is coursework aligned with current educational leaders' standards?

3. What areas need to be addressed to close gaps from what is learned during the coursework to what principals face on a daily basis?

4. What coursework is specifically geared towards special education and what information is disseminated during those courses?

5. In order to enact change to graduate coursework, what steps must be taken at your university?

Thank you very much for your time today. You have shared a great deal of information, which will be very helpful in my research regarding Principals' perception of special education training received. Is there anything else that you would like to add regarding this topic? 


\section{VITA}

Lucas “Luke” William McCoy was born in St. Joseph, MO to Larry and Judy McCoy and attended public schools in St. Joseph until graduating from Benton High School. Luke was always engaged in athletics and could often be found at the local park playing baseball with friends or shooting baskets on any playground that his parents would allow him to walk or ride his bike to.

During his time at Benton, he was active in athletics, various clubs, student council and the National Honor Society. It was also during this time that he earned the Eagle Scout award for his work in the Boy Scouts of America. Upon graduating, Luke received a Presidential Scholarship to attend Northwest Missouri State University in Maryville, MO and graduated with a degree in Secondary Science Education, Unified Science with an emphasis in Chemistry.

Luke was hired by the St. Joseph School District to teach Chemistry at Central High School. This was a proud moment for Luke as he taught in the same room that his Uncle, Dr. Bill McLaughlin (State Teacher of the Year and textbook author), had taught in previously for many years. Luke helped start the girls' softball program, eventually becoming the head coach and guiding the team into competitive program with several student-athletes going on to play at the collegiate level.

In 2000, Luke married his best friend and love of his life, Rachel. They rented an old, small farmhouse and enjoyed walking through the pastures and woods. They enjoyed traveling and spent time in Colorado, Tennessee and the outer banks of North Carolina. In 2003, they wanted to start a new adventure and moved to Columbia, MO. There, Luke wanted to try a different career path and was hired by 
the Boy Scouts of America to be a district executive. While this was an incredibly fulfilling position, Luke missed the classroom. However, it was this experience that led him to open up to the possibility of becoming a Principal at some point. Luke was hired to teach chemistry at Columbia Hickman High School in 2005.

After teaching for 2 years at Columbia Hickman and also earning his Master's degree in Secondary Administration, Rachel and Luke headed back to St. Joseph and Luke accepting a position as Assistant Principal at Bode Middle School. They also were bringing home their first child, Elliot William.

Luke and Rachel had their second child, Noah Harrison, upon moving back to St. Joseph. That year also brought another change as a position opened up at Benton High School for an Assistant Principal. Luke was very excited for the opportunity to give back to the community in which he was raised. He was also excited to bring home a $3^{\text {rd }}$ child, Lowell “Ben” Benjamin, two years later.

Through the years, Luke has helped improve the graduation rate and attendance rate of students at Benton High School. He likes to counsel students and help them with life altering decisions. He also enjoys the camaraderie with teachers, administrators and other staff members. It is a true family at Benton High School, and it is important for him to continue to grow and nurture other staff members as a leader of the community. He has won Northwest Missouri Assistant Principal of the Year twice, in 2011 and again in 2018.

Leading others has always been a passion for Luke. Whether in Scouts as a youth, as a Coach, as a Teacher or as an Administrator he has looked for opportunities to help others and foster lasting relationships. Luke, with Rachel, now 
spends a lot of his time once again on the local baseball fields and playgrounds watching his three sons dribble, shoot, hit, run and throw. 